\author{
MATEUSZ RODAK \\ https://orcid.org/0000-0003-4665-6833 \\ Instytut Historii im. Tadeusza Manteuffla PAN, Warszawa
}

\title{
FENOMEN HAZARDU („HAZARDZIKU”) ULICZNEGO W DRUGIEJ RZECZYPOSPOLITEJ. CASUS WOJEWÓDZTWA WILEŃSKIEGO
}

\begin{abstract}
Abstrakt: W październiku 1927 r. weszło w życie prezydenckie rozporządzenie, które regulowało zasady postępowania $z$ osobami uzależnionymi od hazardu. To pierwsze świadectwo zmiany paradygmatu w myśleniu o tych, którzy nie radzili sobie z nałogiem. W praktyce nowe przepisy niewiele zmieniały, niemniej wykpiwany dotychczas problem powoli stawał się elementem dyskursu m.in. medycznego. W obawie przed niekontrolowanym rozwojem instytucji oferujących możliwość udziału w rozrywkach stricte hazardowych (loterie, wyścigi, zakłady bukmacherskie, kasyna itd.) już u zarania Drugiej Rzeczypospolitej wprowadzono monopol loteryjny. Upaństwowiono również proceder wyścigów konnych. Równocześnie jednak z państwowymi, legalnymi formami hazardu działało w Polsce międzywojennej podziemie hazardowe, to „ekskluzywne" (ruleciarnie), i to plebejskie. Temu drugiemu poświęcony jest niniejszy artykuł.
\end{abstract}

Słowa kluczowe: hazard, Druga Rzeczpospolita, Wilno, województwo wileńskie, prawo, prawo skarbowe, loteria.
Abstract: In October 1927, a presidential decree entered into force that regulated the treatment rules of gambling addicts. It was the first evidence of a change in thinking about those who could not cope with addiction. In practice, the new regulations did not change much; nevertheless, the problem that had been ridiculed until then slowly became an element of discourse, also a medical one. In fear of the uncontrolled development of institutions offering the opportunity to participate in strictly gambling entertainment (lotteries, races, bookmakers' bets, casinos, etc.), a lottery monopoly was introduced at the dawn of the Second Republic of Poland. Horse racing was also nationalised. At the same time, however, together with state legal forms of gambling, the gambling underground was operating in interwar Poland, both the 'exclusive' (roulette parlours) and the plebeian one. The article deals with the latter.

Keywords: gambling, Second Republic of Poland, Vilnius, Vilnius Voivodeship, law, fiscal law, lottery. 


\section{Wstęp}

W 1932 r. legły w gruzach plany stworzenia w Otwocku pierwszego polskiego kasyna ${ }^{1}$. Jedynymi legalnymi, koncesjonowanymi przez państwo formami hazardu pozostawały loteria państwowa i wyścigi konne. Przy czym wokół tych ostatnich funkcjonowała, także przed 1918 r., rozbudowana sieć nielegalnych zakładów bukmacherskich, które skutecznie konkurowały z oficjalnymi biurami przyjmującymi zakłady². Drobne, najczęściej jednoosobowe „przedsiębiorstwa”, w których na przenośnych stolikach przyjmowano nielegalne zakłady, należy potraktować jako rodzimą wersję uniwersalnego zjawiska3 ${ }^{3}$. Bez względu jednak na jego rozmiary czy charakter, fenomen ten pozostawał w Polsce przywilejem dostępnym mieszkańcom miast, w których odbywały się wyścigi konne. W innym miejscu analizowałem zjawisko wielkomiejskiego (w zasadzie warszawskiego) nielegalnego hazardu ${ }^{4} \mathrm{w}$ Drugiej Rzeczypospolitej ${ }^{5}$. Przyjrzałem się wówczas tym jego odmianom, które warunkowo określić można jako „elitarne” (nielegalne domy gry, tzw. ruleciarnie) ${ }^{6}$.

1 Takie plany miał otwocki magistrat, który szukał pomysłu na to, jak wykorzystać wybudowany z pożyczki ulenowskiej gmach miejskiego uzdrowiska, na którego utrzymanie nie było stać władz miejskich, Kasyno w Otwocku, „Robotnik” 27 VII 1932, 253, s. 2; Prawda o domach gry w Polsce. Rozmowa $z$ wiceministrem S. Starzyńskim, „Polska Zbrojna” 16 III 1932, 76, s. 7.

2 M. Rodak, Nielegalny hazard w II Rzeczypospolitej. Rekonesans badawczy, RDSG 71, 2011, s. 60.

${ }^{3}$ Nie wydaje się, żeby zjawisko pokątnego bukmacherstwa przybrało w Drugiej Rzeczypospolitej takie rozmiary, jakie notowano w tym samym czasie m.in. w Wielkiej Brytanii. Działające wówczas np. w Londynie czy Birmingham grupy przestępcze rywalizowały ze sobą nie tylko o wpływy z nielegalnych zakładów, ale również o przychody z innych pozaprawnych źródeł (handel bronią, narkotykami etc.). Zmagania między nimi prowadziły nierzadko do rozlewu krwi, co w istotny sposób przyczyniało się do brutalizacji życia na ulicach największych brytyjskich miast. Wojny bukmacherskich gangów stały się w latach dwudziestych jednym z najpoważniejszych problemów społecznych, z którymi przyszło zmierzyć się służbom porządkowym Wielkiej Brytanii. Por. H. Shore, London's Criminal Underworlds, c. 1720 - c. 1930. A Social and Cultural History, Basingstoke 2015, s. 167 nn.; eadem, Criminality and Englishness in the Aftermath. The Racecourse Wars of the 1920s, „Twentieth Century British History” 22, 2011, 4, s. 481-484.

${ }^{4}$ W tym miejscu przez „hazard” rozumiem wszelkie gry, w których o wygranej nie decydują umiejętności (zręczność, kalkulacja matematyczna), ale wyłącznie los. Takie ujęcie mieści się w wąskim zakresie rozumienia pojęcia hazardu. Por. L. Wilk, Hazard. Studium kryminologiczne i prawne, Warszawa 2012, s. 1-2. Istotne znaczenie ma oczywiście kwestia uczciwości organizatora gry oraz graczy, którzy w różnym stopniu mogą wpływać za pomocą oszustw na ostateczny efekt gry.

${ }^{5}$ M. Rodak, op. cit., passim.

${ }^{6}$ Por. rozróżnienie na hazard dla biednych i bogatych stosowane przez Suzanne Morton, At Odds. Gambling and Canadians 1919-1969, Toronto 2003, s. 42. 
W działających w miastach „domach gry” spotykamy przedstawicieli różnych grup społecznych. Najczęściej bywali to reprezentanci szeroko rozumianych środowisk robotniczych, rzemieślniczych i drobnomieszczańskich. W lokalach o lepszej „renomie” trafiamy na osoby - z reguły uzależnione od hazardu - związane z ówczesną elitą finansową lub intelektualną kraju czy miasta. Dużą grupę stanowili studenci. Trafiali tam również, często zwabieni, odwiedzający miasta włościanie. Ich obecność w „ruleciarniach” to jednak raczej wyjątek niż reguła. Przy czym im mniejsze miasto, tym częściej wśród grających zdarzały się osoby z prowincji. Naturalnie była to forma hazardu niedostępna dla młodzieży, tym bardziej dzieci.

Nielegalne „domy gry” oraz pokątni bukmacherzy to tylko dwa przykłady odmian ówczesnego hazardu. Wszyscy ci, którzy chcieli grać, a nie było ich stać na grę na wyścigach lub udział w stosunkowo drogiej loterii państwowej ${ }^{7}$, mogli szukać okazji w restauracjach, barach, piwiarniach, gdzie grano w domino, karty czy kości. Najczęściej była to jednak działalność na pograniczu oszustwa i hazardu ${ }^{8}$. Ostatecznie można było skorzystać, i tak czyniła zdecydowana większość, z bogatej oferty gier, które dostępne były wprost na ulicy, nie tylko w czasie wszelkiego rodzaju jarmarków, targów, odpustów czy zabaw. Oferowane tam formy hazardu funkcjonowały w rzeczywistości miejskiej i wiejskiej, nie znały ograniczeń wiekowych, społecznych ani materialnych. Pozostawały elementem zjawiska uniwersalnego ${ }^{9}$, oswojonego i posiadającego długą tradycję, a przy okazji symptomatycznego dla społeczności żyjących w warunkach gospodarki przedkapitalistycznej (względnie w „posttradycyjnym” sektorze społecznym) ${ }^{10}$.

7 P. Grata, Monopol loteryjny w Polsce w latach 1920-1939, „Prace Historyczno-Archiwalne" 15, 2005, s. 135.

${ }^{8}$ Por. M. Rodak, op. cit., s. 55-56.

9 Kanadyjska badaczka pisze o „wszechobecności” hazardu groszowego (,penny gambling”) w Kanadzie okresu międzywojennego, S. Morton, op. cit., s. 49-50.

10 A. Nowak, Kupowanie nadziei. Loteria w Królestwie Polskim (1815-1867), Warszawa 2017, s. 42; P. Grata, Monopol loteryjny, s. 130. Określenie „posttradyjny” stosuję za W. Mędrzecki, Społeczeństwo, w: Wokół nowej syntezy dziejów Drugiej Rzeczypospolitej, red. W. Mędrzecki, Warszawa 2019 (Metamorfozy Społeczne, t. 22), s. 140-141. Por. badania na temat loterii liczbowych w Harlemie w okresie międzywojennym, S. Louw, Numbers Games, Race, Gender, Power. Primitive Accumulation in the Black Metropolis, „Safundi. The Journal of South Africa and America Studiers" 21, 2020, 1, s. 49 oraz S. White, S. Garton, S. Robertson, G. White, Playing the Numbers. Gambling in Harlem between the Wars, Cambridge Mass. 2010. Przy czym w tym przypadku mowa o rozbudowanym przedsiębiorstwie biznesowym, w którym losowość z czasem przestała mieć jakiekolwiek znaczenie. W latach trzydziestych, kiedy większość wyników gier była ustalana z góry, kontrolę nad nimi systematycznie przejmowali już biali (głównie włoscy) gangsterzy. 
W „Dzienniku Wileńskim” z 1928 r. możemy znaleźć następujący opis fenomenu określanego jako „hazard uliczny” (względnie ,jarmarczny”): „Ulica Syrokomla, Plac Łukiski i inne, nawet Plac Katedralny, stale są obsadzone stolikami, przy których zgrać się może łatwowierny. Tu kręcące się «koło szczęścia», tam «cetno i licho», tu «3 karty», tam «naparstki» lub «pasek», albo dla odmiany «kostki», gdzie za «rzut» płaci się 50 groszy, a nie wygrywa się nigdy"11. Nieco przekornie autor określał te formy rozrywki mianem "hazardziku”, który odbywać się miał w ciągu dnia, w miejscach publicznych, w zasadzie bez żadnej kontroli.

Międzywojenni „ruleciarze”, samozwańczy bukmacherzy czy szulerzy trafiali przed oblicze sądu jako sprawcy przestępstw czy wykroczeń skatalogowanych w kodeksach. Organizatorów nielegalnych loterii fantowych, względnie gier o zbliżonym charakterze, które mogły być traktowane jako specyficzne przejawy hazardu, traktowano jako przestępców skarbowych. Ich działalność, lokująca się na styku drobnego handlu i rozrywki, najczęściej prowadzona bez stosownych pozwoleń, to szara strefa ówczesnego „przemysłu” quasi-hazardowego. Oferowane przez nich usługi umieścić można między nielegalnymi i legalnymi formami hazardu. To oni i uprawiany przez nich proceder pozostają w centrum moich zainteresowań.

W artykule pominąłem zjawisko organizacji gier, bardzo popularnych m.in. na ulicach Warszawy, typu „trzy blaszki”, „trzy karty”. Zwycięstwo w tego typu grach zależało od spostrzegawczości gracza, a przegrana od umiejętności manipulacji organizatora. $\mathrm{W}$ badanym okresie nie były traktowane jako hazardowe. Nie zmienia to faktu, że stanowiły bardzo ważny element ulicznego (plebejskiego), głównie miejskiego „przemysłu” rozrywkowego. Nie zajmowałem się również fenomenem gry w karty. To po pierwsze temat na odrębne badania, po drugie granica między hazardową grą a szulerstwem pozostaje w zasadzie nieuchwytna. Przy czym zdaję sobie sprawę, że zarówno podrzędne knajpy, jak i eleganckie lokale, tak w Wilnie, jak i w większości ówczesnych miast, pełne były rozpalonych namiętnością do kart graczy, którzy przegrywali nierzadko znaczne sumy.

Najważniejsze regulacje dotyczące monopolu loteryjnego wydano w 1920 oraz w 1936 r. ${ }^{12}$ Na Wileńszczyźnie obowiązywały od roku $1923^{13}$. Wszelkie loterie wymagały zgody stosownych władz skarbowych. Gry (loterie fantowe, „koła szczęścia”, gry tombolowe np. bingo), których

${ }^{11}$ Hazardzik kwitnie, „Dziennik Wileński” (dalej: DW) 9 VI 1928, 129, s. 3.

12 P. Grata, Monopol loteryjny, s. 129; „Ustawa w przedmiocie urządzania loterii i założenia Polskiej Państwowej Loterii Klasowej”, Ustawa z dnia 9 lipca 1936 r. o monopolu loteryjnym, Dz. U. 1936, poz. 607.

${ }_{13}$ Ustawa z dnia 5 grudnia 1923 r. o rozciagnięciu na obszar..., Dz. U. 1923, poz. 1063. 
kapitał nie przekraczał 1000 zł, urządzano za zgodą izb skarbowych lub urzędów skarbowych, akcyz i monopoli skarbowych ${ }^{14}$. W województwie wileńskim urzędy te mieściły się w Wilnie i Wilejce, a w nowogródzkim w Lidzie i Baranowiczach ${ }^{15}$. Organizatorzy gier, którzy nie posiadali zgód właściwych władz skarbowych, karani byli na podstawie przepisów prawa karno-skarbowego (z lat 1926, 1932, 1936). Oskarżonym groziły kary grzywny nawet do 20 tys. zł i/lub aresztu oraz konfiskata przedmiotów użytych do gry. Nad przestrzeganiem przepisów czuwali urzędnicy kontroli skarbowej ${ }^{16}$. Prace - w mundurach lub w cywilu - wykonywali nierzadko w asyście policji, z którą kontrolowali wyznaczone rejony, przede wszystkim miejsca, w których gromadzili się ludzie, odbywał się handel lub trwały imprezy rozrywkowe. Na podstawie wyników ich pracy decyzję o wszczęciu postępowania podejmowała prokuratura. W związku z tym, że za organizację loterii groziły tak kary grzywny, jak i pozbawienia wolności, organem wydającym wyrok był sąd, który rozpatrywał sprawę na wniosek prokuratury ${ }^{17}$.

Analizę zjawiska przeprowadzę, przyglądając się środowisku organizatorów gier działających w Wilnie i województwie wileńskim. Bazę źródłową stanowią akta międzywojennej prokuratury wileńskiej przechowywane w Lietuvos Centrinis Valstybés Archyvas w Wilnie oraz miejscowa prasa. W zespole wileńskiej Prokuratury Sądu Okręgowego w Wilnie zachowały się akta dotyczące 299 spraw, które wszczęto z oskarżenia o organizację nielegalnych loterii, gier fantowych i/lub hazardowych w latach 1921, 1925, 1927-1939. Z grupy tej losowo wybrałem 141 teczek z lat 1927$1939^{18}$. Dla porządku przypomnieć należy, że obszar Sądu Okręgowego w Wilnie poza województwem wileńskim obejmował również północne powiaty województwa nowogródzkiego (szczuciński, lidzki i wołożyński) ${ }^{19}$.

Widoczny na wykresie trend należy wiązać z kolejnymi zmianami w prawie karno-skarbowym. Dużą liczbę spraw z 1934 r. tłumaczyć można również masową akcją kwestionowania aparatów do gry firmy Suchard.

${ }^{14}$ P. Grata, Monopol loteryjny, s. 132; Rozporzadzenie Ministra Skarbu w porozumieniu z Ministrem Sprawiedliwości z dnia 7 maja 1924 r. dotyczace wykonania ustawy z dnia 26 marca 1920 r. w przedmiocie urzadzenia loterii i założenia..., Dz. U. 1924, poz. 541.

15 Kalendarz informacyjny dla urzędników państwowych na rok 1939, oprac. J. Meksz, Warszawa 1939, s. 179-180.

16 P. Grata, Monopole skarbowe w polityce podatkowej Drugiej Rzeczypospolitej, Rzeszów 2009, s. 341-342.

${ }^{17} \mathrm{~W}$ przypadku gdy przestępstwo było zagrożone wyłącznie karą grzywny, wyrok wydawały organy władzy skarbowej.

18 Z lat 1921 i 1925 zachowały się tylko dwie teczki.

${ }^{19}$ Kalendarz informator sądowy na 1938 r., oprac. J. Kirkiczenko, M. Kraczkiewicz, K. Rudzisz, Warszawa 1938, s. 38. 
Sprawy - prawie wszystkie umorzone - wszczęte z tego tytułu stanowiły co najmniej 20 proc. spośród rozpatrzonych przez Sąd Okręgowy w 1934 r. Szerzej piszę o tym niżej. Nawet jeśli ich nie uwzględnimy, to nadal przedostatni rok kryzysu prezentuje się wyjątkowo. Każda z kolejnych zmian prawa przypuszczalnie stawała się impulsem do aktywniejszej działalności kontrolerów, przy czym jest prawdopodobne, że wzrosty z pierwszej połowy lat trzydziestych (w tym specyficzny rok 1934) należy wiązać również z kryzysem ekonomicznym. Nie jestem niestety w stanie stwierdzić, jaką zachowany materiał stanowi część w stosunku do rzeczywistej liczby prowadzonych spraw.

Wykres 1. Liczba spraw wszczętych z tytułu prowadzenia nielegalnej loterii zachowanych w zespole Prokuratury Sądu Okręgowego w Wilnie z lat 1921-1939

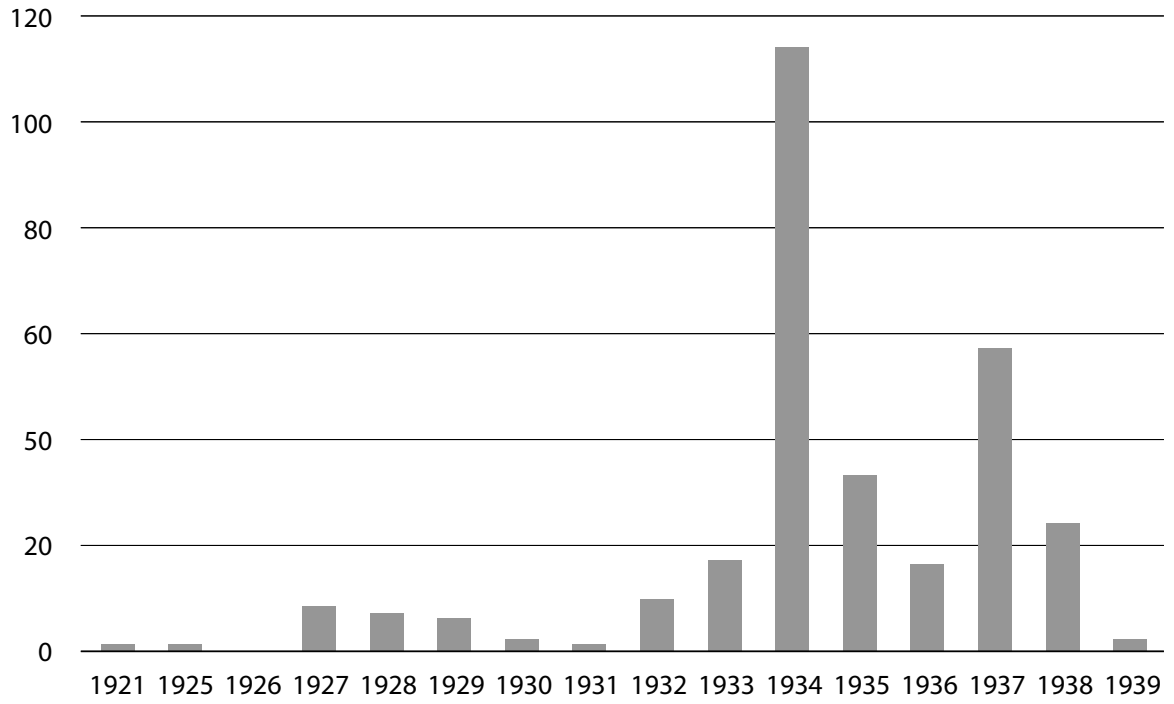

Źródło: Lietuvos Centrinis Valstybės Archyvas, Prokuratura Sądu Okręgowego w Wilnie.

Jest to pierwsza w polskiej historiografii próba opisu tego zjawiska w Drugiej Rzeczypospolitej. Badaniami objęty został teren tylko jednego województwa (do 1926 r. oficjalnie Ziemi Wileńskiej) ${ }^{20}$, w którym przepisy skarbowe obowiązywały dopiero od $1922 \mathrm{r} .{ }^{21}$ Wiele ze sformułowanych w tym miejscu wniosków traktować powinno się jako bardzo

${ }^{20}$ W artykule będę używać sformułowania „,województwo wileńskie”.

${ }^{21}$ Izbę skarbową w Wilnie powołano na mocy rozporządzenia ministra skarbu z 11 lipca 1922 r., Rozporzadzenie Ministra Skarbu z dnia 11 lipca 1922 r. w przedmiocie utworzenia izby skarbowej i urzędów skarbowych na obszarze ziemi Wileńskiej, Dz. U. 1922, poz. 522. 
wstępne. W przyszłości należy dokonać szerszych analiz o charakterze porównawczym.

W artykule chciałbym przyjrzeć się kilku kwestiom, które wydają się kluczowe dla ogólnej charakterystyki zjawiska nielegalnego quasi-hazardu w Drugiej Rzeczypospolitej.

1) Pierwsza i podstawowa dotyczy sprecyzowania samego problemu. Czy opisywany fenomen można traktować jako formę hazardu, czy raczej jego surogat? By odpowiedzieć na to pytanie, dokonam m.in. opisu najpopularniejszych form nielegalnych gier. Granica między tym, co było loterią, a co nią nie było, o czym niżej, bywała bowiem niezwykle cienka i nierzadko uznaniowa.

2) Dyskursowi eksperckiemu towarzyszyła, dość jednostronna, narracja ówczesnej prasy. W kilku zdaniach podsumuję opinie wileńskich dzienników na temat quasi-hazardu. Wydaje się, że była ona reprezentatywna dla całego kraju.

3) W dalszej kolejności postaram się scharakteryzować środowisko organizatorów i odbiorców tych form rozrywki.

\section{Czy to już hazard? Wybrane przykłady gier}

Kontrolerzy skarbowi wielokrotnie zmuszeni byli podejmować decyzje w kwestii, czy loteria jest legalna, czy nie (tj. ustalić, czy jej organizator miał na nią pozwolenie), ale również, czy konkretna gra nie posiadała cech gry zabronionej - hazardowej (tj. czy w ogóle jest to loteria). Nie udało mi się ustalić ogólnej liczby dokonanych kontroli, stąd nie sposób określić, jaki odsetek stanowiły sprawy skierowane do sądu. Analiza źródeł wskazuje natomiast, że uniewinnieniem kończyło się około 10 proc. z nich ${ }^{22}$. $\mathrm{W}$ rozdziale przedstawię najczęściej spotykane gry, które znajdowały się w kręgu zainteresowania kontrolerów. Opiszę jednocześnie przykłady problemów, które pojawiały się, kiedy należało dokonać interpretacji zjawiska. Przy czym mowa w tym miejscu będzie zarówno o wsi, jak i miastach.

\section{Loterie fantowe}

Zdecydowanie najczęściej spotykane były różnego rodzaju loterie, z reguły fantowe - było to 90 spraw, które stanowiły 63,8 proc. wszystkich. Felietonista „Dziennika Wileńskiego” ironizował: „Do uruchomienia

22 Spośród 149 oskarżonych uniewinniono 15 osób. 
takiej imprezy używa się: składanego stoliczka, takiego, który na widok policjanta składa się automatycznie, dobrych i zdrowych nóg, które mogą unieść stolik i jego właściciela w odpowiednim tempie z jednej ulicy na drugą. Zakładowego kapitału jeden złoty. Siedem brudnych cukierków i zakład gotowy"23. Rzeczywiście nie był to proceder wymagający znacznych nakładów finansowych.

W sprzedawanych pojedynczo, jako losy, cukierkach lub czekoladowych kostkach znajdowały się kartki z numerami, względnie z rysunkiem, literą itd. Rzeczywista wartość sprzedawanych po 5, 10 czy 20 gr słodyczy nie przekraczała 1-3 gr ${ }^{24}$. Często podkreślano ich fatalną jakośćc5. Nagrodę w postaci różnych drobiazgów ${ }^{26}$, względnie kolejnego cukierka, czasem całej bombonierki, wygrywała osoba, która trafiła na konkretny numer, wylosowała najwyższy numer lub w ogóle znalazła pod opakowaniem kartkę z symbolem.

Loterie mogły mieć również formę klasycznego losowania. Gracze po opłaceniu losu wyciągali go z woreczka, pudełka czy szuflady. Najczęściej spotykanym wariantem było losowanie kartki, względnie drewnianej kostki z najwyższym czy wybranym wcześniej numerem, symbolem, kolorem itd. Tego typu loterie stanowią stosunkowo niewielką część wszystkich spraw dotyczących loterii jako takich (około 30 proc.). Organizowano również nielegalne loterie fantowe (określane jako „amerykańskie”), w których sprzedawano losy i spośród nich losowano zwycięski²7.

${ }^{23}$ M. Junosza, Wędrowne garbarnie, DW 29 IX 1933, 265, s. 2.

24 Akta sprawy przeciwko Piotrowi Hajdukowi, 1936-1937, Lietuvos Centrinis Valstybės Archyvas (dalej: LCVA), Prokuratura Sądu Okręgowego w Wilnie (dalej: PSO), sygn. 54121. Hajduk, który miał pozwolenie na sprzedaż czekoladowych kostek o wartości 1 gr, sprzedawał je po 10 gr. Akta sprawy przeciwko Mendlowi Ginzburgowi, 19341935, ibidem, sygn. 54126; Akta sprawy przeciwko Michałowi Szydłowskiemu, 1937, ibidem, sygn. 54250.

${ }^{25}$ „Kurier Nowogrodzki” tak charakteryzował opisany wyżej proceder: „Chociaż sprzedawane przez tych typków czekoladki stanowią najgorszą tandetę anonimowego wyrobu, zaś dzieciak za te same 5 groszy może kupić dobrą i znacznie większą czekoladkę znanej firmy w każdym sklepie - hazard robi swoje i dziatwa obiega stoliki drapichrustów, kupując czekoladki w nadziei, że będzie zawierała «szczęśliwy» numerek, uprawniający do otrzymania gratis drugiej czekoladki”, „Popadła się” Franciszka!, „Kurier Nowogrodzki" (dalej: KN) 2 II 1935, 32, s. 5.

26 Akta sprawy przeciwko Bronisławowi Żylińskiemu, 1939, LCVA, PSO, sygn. 54314. W raporcie urzędnika zatrzymującego organizatora nielegalnej loterii znalazł się szczegółowy spis „fantów” do wygrania. Znalazły się tam m.in. 4 lusterka, brzytwa, żelazko małe, 12 ołówków, 47 agrafek, 168 guzików, 21 szpulek nici, 6 gumek do ołówków, 5 zegarków dziecinnych, 2 gwizdki, 11 broszek. W sumie w wyniku przeprowadzonej po skonfiskowaniu ww. przedmiotów licytacji uzyskano 5 zł i 22 gr.

${ }^{27}$ Akta sprawy przeciwko Srulowi Izraelowi Bankowi, 1931-1932, LCVA, PSO, sygn. 54045. 
Zachowały się akta kilku spraw, w których pojawiły się specjalne aparaty do gry, przede wszystkim firmy Suchard, nazywane „Kupujesz co widzisz" i tak reklamowane ${ }^{28}$. Wszystkie przypadki pochodzą z okresu od kwietnia do września 1934 r. Mechanizm działania aparatów był prosty. Były to skrzynki, w których w przegródkach znajdowały się czekoladki w różnokolorowych opakowaniach. Po wrzuceniu 25 gr z pudełka wypadała jedna z czekoladek. Produkt został dopuszczony do sprzedaży, niemniej drobna modyfikacja wprowadzana przez właścicieli urządzeń (zakrycie otworów, w których znajdowały się czekoladki), zmieniała charakter urządzenia, nadając losowaniu cechy hazardu ${ }^{29}$. Brak stosownych wytycznych doprowadził do tego, że w połowie $1934 \mathrm{r}$. wileńscy urzędnicy zaczęli masowo konfiskować aparaty, nie tylko te przerobione. Wątpliwości rozwiązać musiał sąd. W marcu 1935 r. „Dziennik Wileński" donosił w sprawozdaniu z rozprawy sądowej, która odbyła się w V Wydziale Karno-Skarbowym Sądu Okręgowego w Wilnie, że po zasięgnięciu opinii Generalnej Dyrekcji Loterii Państwowej sąd uznał aparaty firmy Suchard za niespełniające cech loterii fantowej ${ }^{30}$. Zarekwirowane aparaty zwrócono właścicielom. Sąd odstąpił od dalszego rozpatrywania sprawy. W końcu w grudniu 1935 r. Ministerstwo Sprawiedliwości wydało okólnik, w którym wyjaśniano, że aparaty typu „Kupujesz co widzisz” nie powinny być traktowane jako forma loterii, „o ile kupujący istotnie ma możność uprzednio upewnić się, jaki towar za płaconą przez siebie kwotę otrzyma" 31 . Z opinią ministerstwa w 1938 r. zgodził się Sąd Najwyższy ${ }^{32}$. W zdecydowanej większości przypadków mamy więc do czynienia ze swoistą formą sprzedaży, najczęściej słodyczy, a dodatek w postaci

${ }^{28}$ Spraw tego typu było w analizowanej próbie 9, co stanowiło 6,4 proc. próby. Intensywna kampania reklamowa „automatów” firmy Suchard (polsko-szwajcarska firma produkująca słodycze, powstała pod koniec lat dwudziestych, z siedzibą w Krakowie) trwała, jak można przypuszczać, w kwietniu 1933 r. Ukazały się wówczas, równolegle we wszystkich dziennikach, w tym w tych, które wydawano w Wilnie, reklamy nowego produktu firmy Suchard.

${ }^{29} \mathrm{Z}$ czasem tego typu urządzeń, wzorowanych na oryginalnym pomyśle firmy Suchard, zaczęło pojawiać się coraz więcej. Lokalne firmy cukiernicze produkowały własne aparaty. W aktach spraw spotykamy również produkcje chałupnicze. Własny aparat $\mathrm{z}$ aż 400 otworami wyprodukował Teodor Król, którego zatrzymano w czerwcu 1934 r. na jednym z wileńskich targów, Akta sprawy przeciwko Teodorowi Królowi, 1934, LCVA, PSO, sygn. 54142. W maju 1934 r. w Zabrzeziu, pow. wołożyński, Kałman Perski udostępnił w swoim sklepie aparat lwowskiej firmy Branka, Akta sprawy przeciwko Perskiemu Kałamanowi, 1934, ibidem, sygn. 54125.

${ }^{30}$ Masowe procesy o aparaty czekoladowe, DW 25 III 1935, 83, s. 5.

${ }^{31}$ Dz. Urz. Ministerstwa Skarbu, 1935, nr 36, poz. 843. Informacje w tej sprawie podała większość ukazujących się wówczas dzienników.

32 „Kupujesz co widzisz”, „Kurier Wileński” (dalej KW) 15 II 1938, 45, s. 7. 
losowania stanowić miał rodzaj zachęty. Tak też z reguły tłumaczyli się oskarżeni. Zatrzymany na jednym z wileńskich rynków Gabriel Żygnol, jak się okazało loteryjny recydywista, twierdził, że „takowej [gry] nie uważa za grę loteryjną, lecz jedynie za sposób ułatwiający mu sprzedaż”33. Co interesujące, argumentu tego często używały osoby już karane za organizację nielegalnych loterii ${ }^{34}$. Spotykamy także inne próby udowodnienia swojej niewinności. Jan Chodaniak, również recydywista, twierdził, że „losowości nie było, bo na kartkach nie były cyfry, ale kropki”35. Ludwik Draga, który na rynku we wsi Okierniki w powiecie wileńsko-trockim urządził loterię, zeznawał, że „chciał w ten sposób uniknąć targowania się i sprzedać szybciej towar"36. Największą grupę stanowili zatrzymani, którzy tłumaczyli się, że nie znali przepisów i nie wiedzieli o obowiązujących zakazach. $Z$ reguły przyznawali się do winy.

Interesujące informacje przynosi treść uzasadnień wyroków. W grudniu 1933 r. na targu w Turgiełach w powiecie wileńsko-trockim dwaj wilnianie, Witold Judycki i Józef Sperski, sprzedawali czekoladki z numerami, przy czym cztery najwyższe numery wygrywały premię. Obydwaj twierdzili, że była to forma sprzedaży premiowej. Tymczasem w uzasadnieniu wyroku sądu, w którym skazano tylko Judyckiego (Sperski skutecznie się ukrywał) na sześć miesięcy więzienia (wyrok łączny z czterech spraw), czytamy, że „w grze tej o wygranej nie stanowiły zręczność, spostrzegawczość lub inne walory intelektualne czy fizyczne osób grających, lecz wyłącznie przypadek, jeżeli tak rzec można, ślepy traf. Gra ta musiała przynosić pewien zysk oskarżonym Judyckiemu i Sperskiemu i przynajmniej zysk pośredni przez ściągnięcie większej ilości nabywców, zachęconych sposobem gry" ${ }^{37}$. Lektura pozostałych uzasadnień jednoznacznie wskazuje, że sądy, wydając wyroki skazujące, zwracały szczególną uwage na dwie opisane wyżej kwestie, tj. przypadkowość oraz dodatkowy zysk, który gra przynosiła sprzedającemu ${ }^{38}$. Podkreślano przy tym, że przypadkowość gry stanowiła jej dodatkowy atrybut, który zinterpretowano jako „zachętę do wzięcia udziału”39. Ważnym argumentem pozostawał

${ }^{33}$ Akta sprawy przeciwko Gabrielowi Żygnolowi, 1934, LCVA, PSO, sygn. 54140. Podobnie por. Akta sprawy przeciwko Janowi Staniakowi, 1937, ibidem, sygn. 54261,

${ }^{34}$ Akta sprawy przeciwko Wawrzyńcowi Jurkowi, 1934, LCVA, PSO, sygn. 54152

35 Akta sprawy przeciwko Janowi Chodaniakowi, 1935, LCVA, PSO, sygn. 54187.

36 Akta sprawy przeciwko Ludwikowi Drago, 1937-1938, LCVA, PSO, sygn. 54287.

37 Akta sprawy przeciwko Witoldowi Judyckiemu i Józefowi Sperskiemu, 1933-1934, LCVA, PSO, sygn. 54158.

38 Podobnie kwestię tę interpretował Sąd Najwyższy. Por. Loteria a aparat „Kupujesz co widzisz”, „Nasz Przegląd” 15 II 1938, 46, s. 12.

39 Akta sprawy przeciwko Berkowi Melnikowi, 1934-1935, LCVA, PSO, sygn. 54016. Z uzasadnienia: „ujmując tę rzecz, ze stanowiska kupieckiego, należy stwierdzić, że gra 
fakt zawyżania wartości „sprzedawanego” towaru w stosunku do jego rzeczywistej wartości ${ }^{40}$. Zdecydowana większość wyroków zapadała jednak z powodu braku urzędowej zgody na przeprowadzenie loterii. Odsetek uniewinnień wśród spraw dotyczących zorganizowania nielegalnych loterii wynosił około 7 proc. Najczęściej sądy podejmowały takie decyzje, jeśli oskarżony urządzał loterię na zlecenie instytucji lub wspólnoty wyznaniowej, względnie udało mu się udowodnić, że prowadził sprzedaż premiową ${ }^{41}$.

\section{Gra w kości}

Kolejną grą, po najczęściej spotykanych loteriach fantowych, która była traktowana jako hazardowa, ergo jako forma loterii, była gra w kości, w tym kilka jej możliwych wariantów. W aktach znajduje się 15 spraw, które dotyczyły 17 osób, co stanowi 11 proc. wszystkich. Ich niewielką liczbę tłumaczyć można m.in. tym, że część incydentów rozpatrywana była przez sądy z oskarżenia o oszustwo. Niewykluczone również, że nie traktowano ich jako hazard, na co wskazuje interpretacja części z wyroków uniewinniających. W końcu, last but not least, na co tym razem wskazywać może niewielkie zainteresowanie prasy, gra w kości nie stanowiła poważnego problemu społecznego.

Najpopularniejszą formą gry w kości były zakłady, w których obstawiano wynik przed wykonaniem rzutu lub tuż po. Rzut wykonywano

ta, urządzona z uwzględnieniem właściwości przeciętnej psychiki ludzkiej, musiała zawierać pewien moment przypadkowości w uzyskaniu nawet nieznacznie różniących się premii, bowiem moment ten stanowi właściwie zachętę do wzięcia udziału w tej grze $\mathrm{i}$ jest nieodzownym warunkiem jej powodzenia. A to jest kardynalna cecha wspomnianej gry, kwalifikująca ją jako grę loteryjną, niezależnie od nazwy, pod którą jest ona znana w obrocie handlowym, na przykład «sprzedaż czekolady sposobem premiowym» itp. Ta gra loteryjna musiała przynosić pewien zysk oskarżonemu Mielnikowi, jest to rzecz pewna i zrozumiała".

${ }^{40}$ Nawet sprzedaż premiowa pozornie wyglądająca na przeprowadzoną prawidłowo mogła w opinii sądu zostać uznana za loterię. W styczniu 1938 r. Gabriel Żygnol na targu w Dziewieniszkach sprzedawał cukierki po 10 gr, kupujący miał prawo losować spośród 114 kartoników, z których każdy coś wygrywał. Sąd uznał, że sprzedaż ta była loterią, a to z tego powodu, że „ilość fantów, których wartość jest wyższa od ceny losu w danym wypadku cukierka, jest dwanaście razy mniejsza od ilości fantów, których wartość jest niższa od ceny losu”, Akta sprawy przeciwko Gabrielowi Żygnoli, 1938, LCVA, PSO, sygn. 54257.

${ }^{41}$ Akta sprawy Wacława Stankiewicz, 1929, LCVA, PSO, sygn. 54035 (prezes koła Ligi Obrony Powietrznej i Przeciwgazowej w Niemenczynie); Akta sprawy Antoniego Twarowskiego, 1936, ibidem, sygn. 54230 (loteria urządzona na polecenie księdza). 
z dłoni, a rozrzucone kości (od 2 do 8) zakrywano kubkiem lub tekturą. Z reguły stawiano 10-20 gr, rzadziej $50 \mathrm{gr}^{42}$. Najczęściej mamy do czynienia z wariantem tej gry, w którym brało udział kilka osób równocześnie ${ }^{43}$.

Specyficzną odmianą, a w zasadzie próbą nadania grze pozorów umownej ekskluzywności, pozostawała rozgrywka, w której wykorzystywano dodatkowe plansze z numerami. Była to zazwyczaj tektura z wyrysowanymi kilkunastoma kwadratami z liczbami, na których gracze kładli zaproponowane stawki ${ }^{44}$. Reportażysta „Dziennika Wileńskiego” notował: „Na kartonie papieru wypisane jakieś cyfry... Kostki grzechoczą w pudełku... Kupkami leżą, poukładane różne groszaki... Padają kostki... - Dziesięć bank wygrywa! Odchodzą jedni przechodnie, do stołu cisną się inni, żądni dreszczyku emocji... I znów padają kości i znów bank wygrywa”45.

Sporadycznie pojawiała się rozbudowana forma planszy. Tekturową kartę lub ceratę dzielono na trzy części. Górna (w czerwonym kolorze) podzielona była na pięć pól (od 2 do 6), podobnie dolna (w niebieskim kolorze, pola od 8 do 12), w części trzeciej (umieszczano ją między pozostałymi polami lub z boku) znajdowało się tylko jedno pole z $\mathrm{nr} 7^{46}$. Gra miała dwa warianty. Jeden przewidywał wygraną za każdy dokonany rzut, przy czym uzyskanie siedmiu oczek uprawniało do wygranej w postaci trzykrotności postawionej stawki. Uzyskanie innej liczby oczek kończyło się wygraną $\mathrm{w}$ postaci $n \mathrm{p}$. drobnych słodyczy. W tym przypadku nie obstawiano konkretnych liczb. Drugi z wariantów wymagał już od graczy wyboru jednej liczby, a wygraną gwarantował wyłącznie rzut zakończony wybraną liczbą oczek. W ten sposób gra stawała się hazardową.

${ }^{42}$ Tylko w jednym przypadku stawka wynosiła złotówkę.

43 Akta sprawy przeciwko Piotrowi Dzicowi, 1935, LCVA, PSO, sygn. 54221. Dzic, złodziej i loteryjny recydywista, został zatrzymany w czasie odpustu we wsi Rymszany powiatu brasławskiego. Korzystał z dość rzadko spotykanego systemu, w którym udział brało pięciu graczy, a każdy z nich wybierał jedną liczbę z przedziałów 5-9, 10-14, 1519, 20-24, 25-29. Rzutu dokonywano pięcioma kośćmi. Wygrywał gracz, który obstawił wyrzuconą liczbę.

${ }_{44}$ Akta sprawy przeciwko Pinchusowi Gellerowi, 1932, LCVA, PSO, sygn. 54107.

${ }^{45}$ M. Junosza, Rozbój na ulicy, DW 29 IV 1932, 98, s. 2.

${ }^{46}$ Akta sprawy przeciwko Bernardowi Glińskiemu, 1931-1932, LCVA, PSO, sygn. 54041. Przykładowa plansza wykonana przez Bernarda Glińskiego, mieszkańca Wilna, zatrzymanego na organizacji nielegalnej gry na targu we wsi Ostrowiec powiat święciański w listopadzie 1931 r.

\begin{tabular}{|l|l|}
\hline \multirow{4}{*}{7 płaci 3 razy tyle } & 23456 \\
\cline { 2 - 2 } & Każdy numer wygrywa \\
\cline { 2 - 2 } & 89101112 \\
\hline
\end{tabular}


Gra w kości jest grą hazardową. Tymczasem, jak się okazuje, w okresie międzywojennym spotykamy różne interpretacje tego zjawiska, nierzadko sprzeczne. W 1937 r. Rubin Kernsztejn urządził grę w kości na targu w Krewie. Sąd powołał się na wyrok Sądu Najwyższego z 1933 r., w którym grę tę uznano za zręcznościową ${ }^{47}$. W innym przypadku sąd wileński stwierdził natomiast, powołując się na opinię biegłych, że gra w kości z pewnością nie jest grą zręcznościową ${ }^{48}$. Co interesujące, w obydwu sprawach zapadł wyrok uniewinniający. Uznano bowiem, że grę w kości należy potraktować jako wykroczenie jako takie i postawić organizatorów gry w stan oskarżenia z powodu złamania przepisów kodeksu wykroczeń. Jednocześnie pozostałe sprawy dotyczące tej gry zakończyły się wyrokami skazującymi. „Rozrywka” potraktowana została jako forma loterii i sprawców ukarano za brak pozwolenia na jej organizację!

\section{„Koła szczęścia” czyli prawie ruletki}

Trzecim najczęściej organizowanym w województwie wileńskim typem gier hazardowych pozostawały „koła szczęścia”, które były prostszą wersją klasycznej ruletki. W aktach prokuratorskich i policyjnych używano określenia „koła szczęścia”, w prasie znacznie częściej, celem podkreślenia ich zgubnego charakteru, stosowano nazwę ruletka. Podobnie jak gra w kości w aktach sądowych znajdujemy je stosunkowo rzadko, w sumie było to 14 spraw, co daje 10 proc. ogółu. Ten niewielki udział tłumaczyć można co najmniej na dwa sposoby. Po pierwsze wymagały znacznie więcej miejsca niż np. loteria cukierkowa. Najczęściej oprócz samego urządzenia na stole znajdowała się także plansza służąca do obstawiania. Szybka likwidacja takich „salonów gier” - jak z ironią pisała o nich wileńska prasa - była znacznie bardziej kłopotliwa niż stoisk z cukierkami czy stolików, na których grano w kości. Jednocześnie, przy braku pozwolenia dużo trudniej, już tylko z powodu specyficznego charakteru aparatu, było udowodnić policji lub urzędnikom skarbowym, że gra nie miała charakteru gry hazardowej. „Koła szczęścia” były bowiem, po uzyskaniu stosownych dokumentów, wykorzystywane również jako specyficzna forma loterii. Sytuacja taka miała miejsce wówczas, gdy grający miał gwarancję, że wygra.

${ }^{47}$ Akta sprawy przeciwko Rubinowi Kernsztejnowi, 1937, LCVA, PSO, sygn. 54260.

${ }^{48}$ Akta sprawy przeciwko Janowi Wójtowiczowi i Mendlowi Judelewiczowi, 19351936, LCVA, PSO, sygn. 54212. 
Mechanizm działania był prosty. Z reguły wykorzystywano koło z umieszczanymi (namalowanymi, przyklejonymi, wypalonymi) przy brzegach liczbami lub kolorowymi polami. W środku znajdowała się obracająca się strzałka. Gracze obstawiali, w zależności od typu urządzenia, kolor lub liczbę ${ }^{49}$. Stawki, podobnie jak w przypadku kości, wynosiły od 10 gr do 1 zł. Wszystkie skonfiskowane przez władze urządzenia były produkowane chałupniczo ${ }^{50}$. W niektórych wypadkach wokół kręcącego się koła, czasem tylko obracającego się drążka, układano fanty. Rzadko zdarzały się urządzenia z dołączonymi przegródkami, w których znajdowały się wygrane. Obydwie wersje traktowano w takich sytuacjach jako formę loterii. Jeśli jednak część przegródek pozostawała pusta, wówczas diametralnie zmieniał się charakter gry. Sytuacje takie musiały zdarzać się wyjątkowo często. W 1930 r. komendant wojewódzki Policji Państwowej w Wilnie wezwał podległych sobie funkcjonariuszy do aktywniejszych działań, których celem miała być „całkowita likwidacja nadużyć” 51 . Rozkaz wydany został w odpowiedzi na to, że „w ostatnich czasach - jak pisał inspektor PP Wiktor Ludwikowski - daje się zauważyć prowadzenie na wielką skalę «Kół szczęścia» i tem podobnych przedsiębiorstw przez osoby prywatne dla celów osobisto-zarobkowych, a tem samem bez zezwolenia władz skarbowych" ${ }^{2}$. Podkreślał przy tym wysoką szkodliwość społeczną tego typu gier.

Żadna ze spraw, które toczyły się przeciwko organizatorom opisanej gry, nie zakończyła się wyrokiem uniewinniającym. Tylko w jednym przypadku doszło do umorzenia. Sprawa dotyczyła recydywisty hazardowego, którego zatrzymano, kiedy próbował uciec z ruletką w plecaku.

49 Spotykamy sytuacje, w których gracz mógł wybierać między liczbą (mniejsza szansa), a kolorem (większa). Tarcza koła pokryta była jednocześnie liczbami i kolorami, które zajmowały większą powierzchnię. Do koła dołączona była cerata z liczbami i kolorami. Akta sprawy przeciwko Franciszkowi Kondratowiczowi, 1934, LCVA, PSO, sygn. 54131.

${ }^{50}$ Jednym z bardziej oryginalnych urządzeń był aparat skonstruowany przez Bazylego Mieszczanina, zatrzymanego w jednej z wsi w powiecie szczucińskim w listopadzie 1935 r. Był to drewniany talerz z wypalonymi dołkami od 1 do 20. Do talerza przymocowana była rurka, przez którą wrzucano metalową kulkę, ta zaś wpadała do jednego z dołków. Mieszczanin był recydywistą, którego rok wcześniej zatrzymano i skazano za urządzanie gry w ruletkę również w jednej ze wsi powiatu szczucińskiego. Wówczas także posługiwał się skonstruowaną samodzielnie ruletką, składającą się z drewnianego, obracającego się talerza, umieszczanego w drewnianej obręczy z powycinanymi otworami, do których wpadała kulka, Akta sprawy przeciwko Bazylemu Mieszczaninowi, 1935, LCVA, PSO, sygn. 54220.

51 „Rozkazy Komendanta Wojewódzkiego Policji Państwowej w Wilnie”, 1930, nr 161, s. 5 .

52 Ibidem. 
Sąd nie był w stanie stwierdzić, czy doszło do gry, a i sam zatrzymany z żalem tłumaczył się, że „we wiosce nie można i nie ma z kim urządzić gry jaką jest ruletka" ${ }^{53}$. Generalnie wszyscy oskarżeni przyznawali się do winy, tłumaczyli się niewiedzą i zapewniali, że prowadzili tylko sprzedaż.

\section{Pozostałe gry}

Do sądu trafiały również sprawy, które dotyczyły osób zatrzymanych za nielegalny wyrób kart do gry i/lub użyczenie lokalu do gry w karty w sumie siedem spraw, co daje 5 proc. próby. Wszystkie, które dotyczyły wyrobu kart, zakończyły się umorzeniem lub uniewinnieniem. $\mathrm{Z}$ reguły oskarżonymi byli nieletni, którzy grą w karty urozmaicali sobie monotonię życia na wsi' ${ }^{54}$. Inaczej Sąd Okręgowy traktował osoby, które udostępniały lokal do gry. Wszystkie zostały skazane.

W końcu odnotowujemy dosłownie pojedyncze przykłady gier, które uznane zostały przez urzędników za posiadające cechy gier hazardowych, a które sąd potraktował jako zręcznościowe (strzelanie do celu, gra w kręgielki [„kręgle kołowe”]). Co interesujące, zdaniem prasy wileńskiej „kręgle kołowe” miały królować na lokalnych ulicach ${ }^{55}$. Mowa o grze, w której metalową kulką wyrzucaną za pomocą sprężyny należało trafić w wytypowany drewniany kręgiel. Organizatorów tego typu rozrywek wileński Sąd Okręgowy uniewinniał. Wyrok uzasadniono tym, że gra miała charakter zręcznościowy, a nie hazardowy.

Umorzeniem lub uniewinnieniem kończyły się również sprawy, których przedmiotem były gry wykorzystujące spostrzegawczość graczy. Mowa w tym miejscu o niezwykle wówczas popularnej grze w trzy blaszki (karty, kubki). Ich obecność w dostępnym materiale potraktować należy chyba jako efekt nadgorliwości urzędniczo-prokuratorskiej. Losy kilkudziesięciu osób inwigilowanych na terenie Warszawy za organizację tego typu gier wyraźnie wskazują bowiem, że byli to w przytłaczającej

53 Akta sprawy przeciwko Bazylemu Mieszczaninowi, 1935, LCVA, PSO, sygn. 54220.

${ }^{54}$ Społeczną rolę kart, gry w karty wśród młodzieży chłopskiej bardzo wyraźnie obrazują wspomnienia wiejskich pamiętnikarzy. Wielu z nich pisze o uzależnieniu od hazardu, grze w karty jako jednej z niewielu dostępnych rozrywek. Czytamy m.in.: „Czas zimowy przepędza się na kartach, tak tej zimy jak i drugiej i poprzedniej, to karty są częstym gościem, bo chłopcy wiejscy nawet i gospodarze to kartami się interesują", Por. Pamiętniki chłopów, nr 1-51, oprac. L. Krzywicki, Warszawa 1935, nr 16, 38, s. 204, 206, $214,505,533,539,552$.

55 „Rozkazy Komendanta Wojewódzkiego Policji Państwowej w Wilnie”, 1930, nr 161, s. 5. 
większości oszuści żerujący na ludzkiej naiwności ${ }^{56}$. Organizowane przez nich gry, bardzo popularne na warszawskich ulicach, nie miały $z$ hazardem właściwie nic wspólnego, niemniej prowadziły do sytuacji, w których gracze biorący w nich udział tracili resztki zdrowego rozsądku i przegrywali wszystkie posiadane pieniądze. Historie tak oszukanych osób jako swoiste exemplum ku przestrodze często pojawiały się wileńskiej prasie ${ }^{57}$.

Nie udało mi się odnaleźć przykładów loterii pieniężnych, zjawiska niezwykle popularnego m.in. w niezamożnych dzielnicach amerykańskich miast ${ }^{58}$. Nie wydaje się, aby wynikało to wyłącznie $z$ tego powodu, że obowiązywał całkowity zakaz ich organizacji. Istotną przeszkodę stanowił fakt, że społeczeństwo było wyjątkowo ubogie i nadal jeszcze dostęp do gotówki pozostawał ograniczony. Wielu włościan i mieszkańców miast nie mogło pozwolić sobie na odłożenie większych sum, które zebrane w jednej puli dawałyby szansę na większą wygraną. W jakimś stopniu zapotrzebowanie na tego typu gry kumulowała oczywiście loteria państwowa. Niewykluczone, że w grę mogły wchodzić również czynniki psychologiczne, np. ograniczone zaufanie do organizatorów czy fetyszyzacja pieniędzy. Jednocześnie przygotowanie loterii pieniężnej wymagało od jej organizatora znacznie więcej czasu i wysiłku. Tymczasem cechą hazardu ulicznego niezmiennie pozostawała jego ulotność.

Wszystkie $\mathrm{z}$ opisanych $\mathrm{w}$ tym miejscu form rozrywki, poza oczywiście wymienionymi w ostatnim punkcie, mogły mieć charakter gier hazardowych. Wystarczył drobny zabieg, by „koło szczęścia”, w którym każdy powinien coś wygrać, stawało się ruletką. Podobnie rzecz miała się z kośćmi czy loteriami cukierkowymi. Istotne znaczenie miał moment, w którym przestawała obowiązywać zasada, że „każdy wygrywa”. Urzędnicy kontroli skarbowej często stawali przed trudnym zadaniem udowodnienia, że zadeklarowana forma sprzedaży premiowej w rzeczywistości była grą hazardową, szczególnie wtedy, kiedy organizator miał stosowne pozwolenie.

Naturalnie większość spraw kończyła się już na etapie, na którym stwierdzono brak stosownych zezwoleń. Uzyskanie pozwolenia wymagało wizyty $\mathrm{w}$ urzędzie, wiązało się z koniecznością wniesienia stosownych opłat i zwrotem 10 proc. utargu. Nie było też gwarancji, że takowe się otrzyma. Notujemy przykłady, w których posługiwano się sfałszowanymi

${ }^{56}$ Mowa w tym miejscu o 38 osobach, które pozostawały w orbicie zainteresowań stołecznego Urzędu Śledczego w latach trzydziestych. We wszystkich przypadkach, jeśli już dochodziło do skazania, karano je za oszustwo.

57 Hazard w tzw. blaszki, DW 9 X 1934, 275, s. 3.

${ }^{58}$ S. Louw, op. cit., s. 32; S. White, S. Garton, S. Robertson, G. White, op. cit., s. 100$101,124$. 
pozwoleniami ${ }^{59}$. Ich brak jednoznacznie oznaczał przestępstwo antymonopolowe, ale nie wiązało się to z oskarżeniem o uprawianie nielegalnego hazardu. W takich sytuacjach urzędnicy nie podejmowali już prób oceny charakteru zakwestionowanej rozrywki. Problem ten zajmował ich $z$ reguły dopiero po stwierdzeniu legalnego charakteru „przedsiębiorstwa”. Z opisów gier, które sporządzano, jednoznacznie jednak wynika, że w zdecydowanej większości był to po prostu hazard. W czasie procesu sądowego kwestia ta mogła wpłynąć na ostateczny wyrok. Jeśli bowiem sąd poza brakiem pozwolenia dopatrzył się również hazardowego charakteru gry, z reguły wymierzał surowszy wyrok.

Nie możemy wykluczyć, że na wynik części z gier realny wpływ mieli organizatorzy, którzy mogli dopuszczać się manipulacji. Ważna jednak w tym miejscu wydaje się również postawa samych graczy, spośród których zdecydowana większość traktowała udział w grze jako szansę na odmianę losu i stosunkowo tanią, dostępną wprost na ulicy formę ekscytującej rozrywki ${ }^{60}$. Rozrywki, której wyjątkowo wiele miejsca poświęcano w ówczesnej prasie.

\section{Wileńska prasa i uliczny hazard}

Międzywojenna prasa, którą warunkowo można potraktować jako wyraziciela poglądów części opinii społecznej, niezmiennie krytycznie oceniała zjawisko ulicznego hazardu. W tekstach, w których podnoszono tę kwestię, powracało kilka stałych elementów.

W pierwszej kolejności pisano o demoralizującym wpływie na życie społeczne czy rodzinne wszelkich odmian hazardu. M. Junosza na łamach „Dziennika Wileńskiego” grzmiał w 1932 r.: „Wypisujemy w prasie sążniste artykuły na Sopockie Kasyno, ziejemy świętym oburzeniem na tajne domy gry, a tolerujemy pod ścianami świątyni najobrzydliwsze wydrwigroszostwo" "61. Podkreślano wielokrotnie, że swobodny dostęp do drobnego hazardu ulicznego należy traktować jako przygrywkę do uzależniania. Felietonista „Kuriera Nowogrodzkiego” przestrzegał: „Nawet

59 Akta sprawy przeciwko Bernardowi Glińskiemu, 1931-1932, LCVA, PSO, sygn. 54041.

60 Autorzy monografii poświęconej fenomenowi gier liczbowych w Harlemie okresu międzywojennego wielokrotnie podkreślają jego kulturowe znaczenie dla afroamerykańskiej społeczności Nowego Jorku. Szczególne znaczenie przypisują panującemu w niej powszechnemu przekonaniu (wierze), że wygrana może odmienić los. Przekonanie to przybrało na sile w okresie wielkiego kryzysu. Por. S. White, S. Garton, S. Robertson, G. White, op. cit., s. $77 \mathrm{nn}$.

${ }^{61}$ M. Junosza, Już raz o tem pisano, DW 15 VI 1932, 13, s. 2. 
te zdawałoby się niewinne imprezy kryją w sobie poważne niebezpieczeństwo jako sui generis «przysposobienie hazardowe» społeczeństwa od lat najmłodszych. Cóż dopiero hazard pieniężny?! Toć to kryminał wyraźny i macherów tego rodzaju należałoby przymykać bez pardonu!"62.

Szczególny niepokój budził fakt, że dostęp do gier hazardowych, które organizowano w przestrzeni publicznej, miały dzieci63. Temu problemowi poświęcona jest zdecydowana większość tekstów prasowych dotyczących opisywanych form rozrywki. W 1929 r. dziennikarz „Słowa”, zestawiając potencjalne niebezpieczeństwo, które z jednej strony grozić miało graczom w Monte Carlo czy Sopocie, z drugiej zaś uczestnikom organizowanych na wileńskich ulicach gier (tu ul. Syrokomli), doszedł do wniosku, że „ten ostatni rodzaj hazardu jest bodaj najniebezpieczniejszy, bo gdy w Monako przegrywa tysiące jakiś król stali czy plantacji gumowych, to tu ofiarą oszustów stają się przeważnie słabo dozorowana dziatwa szkolna, wyrostki różnego typu i autoramentu i nędza, która liczy na powiew szczęścia, ryzykując ostatnią 20-groszówką, aby zdobyć kilka złotych bodaj” 64 . W innym miejscu czytamy następujące wezwanie: „Hazard uliczny wciągający w swą orbitę przede wszystkim dzieci i młodzież, w ogóle musi zniknąć z ulic naszego miasta" ${ }^{65}$. Obawy te podzielała Generalna Dyrekcja Loterii Państwowej, która np. w 1930 r. w trosce o los młodzieży, a także „szerokich mas sfer uboższych”, zdecydowała o ograniczeniu wydawania pozwoleń na organizowanie loterii typu „koło szczęścia”66.

Obok dzieci i młodzieży w wileńskich dziennikach wyjątkowo często pojawia się figura biedaka, który stawia swój ostatni grosz i przegrywa. W „Dzienniku Wileńskim” w jednym z felietonów Junoszy z 1932 r. czytamy: „Boże! Wieleż na tym świecie głupoty... Biedacy łożą przecież na te stoły niejednokrotnie ostatnie groszaki" ${ }^{67}$. Ten sam niestrudzony felietonista, tym razem w „Słowie”, w 1934 r. pisał: „Niewinna [--] gierka w karmelki przeradza się w ordynarny hazard i to hazard z góry zszulerowany na niekorzyść ponitera - biedaka, któren by mógł za te, niekiedy bardzo ciężko zapracowane grosze, kupić chleb dla swojej dzieciarni”"68.

62 Przechodzień, W szponach hazardu ulicznego, KN 13 VI 1933, 159, s. 3.

${ }^{63}$ Troska o los dzieci - uczestników gier loteryjnych - miała charakter uniwersalny. Por. S. Morton, op. cit., s. 33-34.

${ }^{64}$ Monte Carlo na alei Syrokomli, „Słowo” 10 II 1929, 34, s. 3.

${ }^{65}$ Przechodzień, W szponach hazardu ulicznego, KN 13 VI 1933, 159, s. 3. W podobnym tonie np. Wciaganie dzieci do hazardu, „Słowo” 13 VI 1935, 159, s. 5.

66 „Rozkazy Komendanta Wojewódzkiego Policji Państwowej w Wilnie”, 1930, nr 161, s. 5.

${ }^{67}$ M. Junosza, Rozbój na ulicy, DW 29 IV 1932, 98, s. 2.

${ }^{68}$ M. Junosza, Uśmiech fortuny, „Słowo” 27 IV 1934, 112, s. 6. 
Dość często wśród grających, obok dzieci, młodzieży oraz pojemnej kategorii, jaką stanowić mieli „ubodzy”, pojawiali się np. żołnierze ${ }^{69}$. Naturalnie nie brakowało wśród grających włościan, którzy odwiedzali m.in. wileńskie targi. „Kurier Wileński” notował: „Na rynku przy zbiegu ulic Kijowskiej i Piłsudskiego rozwinęła się na szeroką skalę gra w prymitywną ruletkę. Najlepszym powodzeniem cieszy się w dni targowe, obierając sobie za ofiary wieśniaków, przybyłych na targ"70. O grających mieszkańcach wsi wspominano jednak dość rzadko ${ }^{71}$. W zasadzie w ogóle nie pojawiały się artykuły, które omawiałyby analizowane zjawisko, uwzględniając perspektywę wsi. Tematyka dotycząca hazardu na wsi ograniczała się do wzmianek na temat plagi karciarstwa, które nie było wówczas zjawiskiem nowym ${ }^{72}$.

Obok artykułów wyrażających troskę o możliwie uzależnienie, w których postulowano ograniczenie dostępu do gier dla dzieci, uboższych czy np. żołnierzy, w wileńskiej prasie pojawiały się także teksty, w których ubolewano nad niekontrolowanym rozwojem zjawiska. „Wszystkie te ponętne zabawy - pisał reportażysta „Dziennika Wileńskiego” w 1928 r. - odbywają się w biały dzień, w publicznych miejscach, a więc chyba za zgodą władz administracyjnych? Czy za oficjalną koncesją, czy za milczącą aprobatą, nie wiemy, ale wiemy, że są i grasują bezkarnie"73. Koniec lat dwudziestych oraz początek trzydziestych obfitowały w teksty, w których niezmiennie zwracano uwagę na bezradność i/lub bezczynność policji, względnie magistratu, a wyjątkowo także i władz skarbowych. Przy czym niezwykle rzadko prasa łączyła opisywane zjawisko z przestępczością skarbową. Generalnie zwracano uwagę na szkody społeczne wyrządzane przez drobny hazard, o negatywnym wpływie na stan finansów państwa w zasadzie zapominając. Niemoc policji w zwalczaniu procederu wiązano z jego efemerycznym charakterem. „Łazik” z „Kuriera Wileńskiego” opisywał czytelnikom klasyczną scenę, w której organizator gry w cukierki na widok policjanta stawał się ich sprzedawcą, a „policjant domyśla się kogo ma przed sobą, nie może jednak ingerować, bo nie złapał jegomościa «in flagranti», tedy z godnością odchodzi i nie zdąży jeszcze roztopić się wśród tłumu, jak gra rozpoczyna się na nowo"74.

69 Przechodzień, W szponach hazardu ulicznego, KN 13 VI 1933, 159, s. 3. W podobnym tonie por. Monte Carlo na alei Syrokomli, „Słowo” 10 II 1929, 34, s. 3.

70 Monte Carlo na ul. Kijowskiej, KW 6 III 1925, 54, s. 3. Por. także np. Plaga oszustw na wileńskich rynkach, KN 7 XII 1934, 335, s. 6.

${ }^{71}$ Nie było to zjawisko nowe. Por. A. Nowak, op. cit., s. 199.

72 Hazard na wsi, DW 8 III 1937, 66, s. 4; Młodzież wiejska, KW 4 II 1938, 34, s. 5.

73 Hazardzik kwitnie, DW 9 VI 1928, 129, s. 3.

${ }^{74}$ Łazik, Wydrwigrosze przy robocie, KW 19 X 1929, 240, s. 3. 
Piętnowano bagatelizowanie problemu ${ }^{75}$. W 1932 r. „Dziennik Wileński” w dziale „Do wiadomości policji” pisał: „Gry hazardowe, o ile wiemy, są zakazane. Niejednokrotnie słyszeliśmy o rewizjach, dokonanych w różnych jaskiniach gry. Tymczasem publicznie w dzień biały, na placach i rynkach hazard kwitnie w najlepsze"76. W zakończeniu odezwy przypominano, po raz kolejny, że „dzieje się to wszystko otwarcie, w oczach policji” oraz z przykrością konstatowano, że „Wilno jest chyba jedynym na świecie miastem, gdzie coś podobnego jest tolerowane"77. Narzekania na niekontrolowany rozwój ulicznego hazardu stanowiły jednak normę we wszystkich miastach Drugiej Rzeczypospolitej ${ }^{78}$.

Zaniepokojeni rozwojem sytuacji dziennikarze proponowali wiele rozwiązań, które miały pomóc w ograniczeniu zjawiska. Najczęściej pojawiały się pomysły radykalne, jak np. bezwzględny, długoterminowy areszt $^{79}$. Namawiano do prowadzenia na szerszą skalę tajnych kontroli ${ }^{80}$. W połowie 1934 r. na łamach „Kuriera Wileńskiego” ukazała się seria obszernych artykułów poświęconych wileńskim „stolikom hazardowym”. Omawiano w nich ponownie cały dotychczasowy zestaw negatywnych skutków społecznych, które swoje źródło miały mieć w „hazardzie najpodlejszego gatunku"81. Od wileńskiego starosty grodzkiego i podległych mu urzędników domagano się natychmiastowych działań. Apele miejscowej prasy oraz opisane wyżej zmiany w prawie, być może również koniec kryzysu, doprowadziły na przełomie 1934 i 1935 r. do istotnych zmian. Fakt ten zauważyli dziennikarze. W listopadzie 1934 r. „Dziennik Wileński" odnotowywał wzmożoną aktywności policji, która na polecenie władz administracyjnych rozpoczęła „ostrą kontrolę wszelkich loterii fantowych urządzanych w Wilnie przez różne organizacje"82. $\mathrm{Z}$ biegiem czasu kontrole tego typu miały zdarzać się częściej83. Podawano liczbę zatrzymanych, niejednokrotnie pojawiały się krótkie notki, w których opisywano przypadki zatrzymania konkretnych osób (wcześniej zdarzały

75 M. Junosza, Rozbój na ulicy, DW 29 IV 1932, 98, s. 2; Obrazki z natury, „Słowo” 12 VI 1932, 134, s. 3.

${ }^{76}$ Do wiadomości policji, DW 7 VI 1932, 128, s. 3.

77 Ibidem.

78 Wciąż naiwność... Jeszcze jedna ofiara hazardu i oszustów, „Kurier Poznański” $10 \mathrm{~V}$ 1927, 211, s. 6; Hazard w kawiarniach krakowskich, „Czas” 27 II 1928, 48, s. 2.

${ }^{79}$ M. Junosza, Wędrowne garbarnie, DW 29 IX 1933, 265, s. 2.

80 Ibidem.

81 Włod., Hazard Wilna. Imprezy bardzo szkodliwe, KW 31 VIII 1934, 237, s. 6.

${ }^{82}$ Kontrola loterii fantowych, DW 19 XI 1934, 315, s. 4.

8350 oszustów rynkowych osadzono $w$ areszcie, „Słowo” 20 X 1934, 287, s. 5; Tępienie hazardu ulicznego, DW 28 VIII 1935, 236, s. 8; Likwidacja ulicznych gier hazardowych, DW 6 IX 1935, 245, s. 8. 
się sporadycznie) ${ }^{84}$. Niemniej zjawisko jako takie nie znikło. Wielokrotnie jeszcze w wileńskich dziennikach temat ulicznego hazardu powracał ${ }^{85}$, nie tak często jednak jak wcześniej.

Wileńską prasę interesowali również, jako wyjątkowo ciekawy fenomen społeczny, organizatorzy gier. Obraz tej grupy malowany był najczarniejszymi barwami. Dominował pogląd, że jest to środowisko skupiające oszustów, naciągaczy, manipulatorów czy szarlatanów ${ }^{86}$. Już same tytuły artykułów pozostają wymownym świadectwem opinii o organizatorach gier: Wydrwigrosze przy robocie, 50 oszustów rynkowych osadzono $w$ areszcie, Oszust, Plaga oszustów na wileńskich rynkach itd. Wielokrotnie podkreślano ich rzekomo odpychający wygląd, zwracano uwagę na ochrypnięty głos, „przebiegłe oczka” czy fakt, że byli pod wpływem alkoholu ${ }^{87}$. Niestrudzony Junosza opisywał wygląd „krupiera”: „Gość taki, o twarzy stworzonej na żywą reklamę monopolu spirytusowego, akcyzowym głosem wykrzykuje" 88 . W końcu zarzucano im agresję wobec graczy, którzy nie zgadzali się z wynikiem gry, względnie wobec osób, które próbowały utrudniać im działalnośćc 89 .

Opisywano również mechanizm działania „lotnych loterii”. Z reguły miały być to dwu-, trzyosobowe konsorcja, w których jedna osoba zajmowała się organizacją, pozostałe werbowały chętnych do gry i/lub ostrzegały przed policją ${ }^{90}$. Przypuszczalnie jednak nie było to zjawisko powszechne. W zgromadzonym materiale źródłowym sprawy, w których przed sądem stawali wspólnicy, to przypadki sporadyczne (około 5 proc. ogółu). Nie oznacza to oczywiście, że zdarzało się to tak rzadko, a przytłaczająca większość organizatorów gier działała samodzielnie. W części przypadków wspólnik, najczęściej wmieszany w tłum, po prostu unikał zatrzymania.

$\mathrm{Z}$ analizy dostępnych danych, także tych opisanych $\mathrm{w}$ tym miejscu, możemy wyciągnąć pewne wnioski na temat specyfiki środowiska organizatorów gier. W następnym rozdziale dokonam krótkiej charakterystyki tej grupy.

${ }^{84}$ Co się zdarzyło wczoraj w Wilnie, DW 30 VII 1937, 207, s. 5.

${ }^{85}$ Plaga oszustw na wileńskich rynkach, KN 7 XII 1934, 335, s. 6.

${ }^{86}$ Obrazki z natury, „Słowo” 12 VI 1932, 134, s. 3.

${ }^{87}$ Monte Carlo na alei Syrokomli, „Słowo” 10 II 1929, 34, s. 3; Do wiadomości policji, DW 7 VI 1932, 128, s. 3; Kiermasz św. Jerzego, „Słowo” 24 IV 1934, 109, s. 5; Hazard Jadwigi, KN 19 XI 1934, 317, s. 4.

${ }^{88}$ M. Junosza, Rozbój na ulicy, DW 29 IV 1932, 98, s. 2.

${ }^{89}$ Moralny obowiazek, „Słowo” 3 VIII 1933, 209, s. 3; M. Junosza, Wędrowne garbarnie, DW 29 IX 1933, 265, s. 2; Monte Carlo na ul. Kijowskiej, KW 6 III 1925, 54, s. 3.

90 Monte Carlo na ul. Kijowskiej, KW 6 III 1925, 54, s. 3. 


\section{Organizatorzy gier. \\ Próba charakterystyki środowiska}

Dysponuję informacjami o 126 osobach (w tym 17 recydywistach, kilku karanych trzykrotnie i więcej razy), które zostały oskarżone o urządzanie nielegalnych loterii, ewentualnie o popełnienie innych przestępstw skarbowych przeciwko monopolowi loteryjnemu ${ }^{91}$. W pojedynczych przypadkach przed sądem stanęli przedstawiciele instytucji, w imieniu których urządzono, jak się okazało, nielegalną loterię ${ }^{92}$.

Felietonista „Kuriera Wileńskiego” przekonywał, że zarówno wśród graczy, jak i organizatorów gier przeważają „obywatele zazwyczaj rodzaju męskiego"93. Wnioski płynące z lektury źródeł sądowych potwierdzają obserwacje dziennikarza. Wśród 126 oskarżonych było aż 116 mężczyzn (93 proc.). W grupie kobiet tylko jedna $\mathrm{z}$ nich była recydywistką. Annę Litwinenko z Mołodeczna zatrzymano co najmniej dwukrotnie, pierwszy raz w 1934 r., kiedy w powiecie wilejskim urządziła nielegalną loterię fantową, drugi raz w $1936 \mathrm{r}$. w powiecie wołożyńskim za organizację ruletki na jednym $\mathrm{z}$ wiejskich rynków ${ }^{94}$. Kobiety oskarżano przede wszystkim o urządzanie loterii fantowych oraz o instalowanie w prowadzonych przez siebie sklepach, piwiarniach czy restauracjach aparatów firmy Suchard. Prawdopodobnie wyjątkowo rzadko dochodziło do współpracy między mężczyznami i kobietami. W grudniu 1936 r. na rynku w jednej z wsi powiatu święciańskiego zostali zatrzymani Regina Łapińska i Piotr Hajduk. Wspólnie urządzili loterię z cukierkami, przy czym Łapińska, która „naganiała” graczy twierdziła, że była to wyłącznie sprzedaż premiowa, na którą pozwolenie miał mieć Hajduk ${ }^{95}$. Ten jako organizator loterii otrzymał stosunkowo wysoki wyrok. Skazano go na grzywnę w wysokości 200 zł i 30 dni aresztu. Łapińska miała zapłacić taką samą kwotę, niemniej kara aresztu wyniosła tylko siedem dni. Niewykluczone więc, że płeć oskarżonych mogła mieć znaczenie przy wydawaniu wyroku ${ }^{96}$.

${ }^{91}$ Do stworzenia krótkiej charakterystyki tej grupy wykorzystałem również akta osób, w sumie 14, które zostały uniewinnione.

92 Por. przyp. 57.

93 Łazik, Wydrwigrosze przy robocie, KW 19 X 1929, 240, s. 3.

94 Akta sprawy Anny Litwinko, 1934-1936, LCVA, PSO, sygn. 54130, 54231.

95 Akta sprawy Reginy Łapińskiej i Piotra Hajduka, 1936-1937, LCVA, PSO, sygn. 54121.

${ }^{96}$ Co interesujące, właścicielka piwiarni w Łyntupach, Luba Mauber, jedna z kilku osób ukaranych za rzekomo niezgodne z instrukcją użytkowanie aparatów firmy Suchard, została skazana na najwyższy wyrok. Musiała zapłacić w sumie 200 zł grzywny oraz odbyć karę siedmiodniowego aresztu. Biorą pod uwagę, że z reguły kary za to wykroczenie nie przekraczały 50 zł i siedmiu dni aresztu, wyrok na Mauber wydaje się 
Obecność kobiet w środowisku organizatorów nielegalnych loterii oraz graczy, o czym szerzej niżej, to w zasadzie wyjątki ${ }^{97}$. Wynikało to prawdopodobnie z co najmniej kilku powodów. Po pierwsze, była to grupa skupiająca ludzi zajmujących się objazdowym handlem, a ten zawsze zdominowany był przez mężczyzn. Dla wielu z organizatorów gier była to forma podreperowania budżetu domowego, względnie, szczególnie w latach trzydziestych, ratunku przed skutkami bezrobocia ${ }^{98}$. Przeprowadzenie gry wymagało spełnienia kilku warunków, które być może mężczyznom było łatwiej urzeczywistnić (donośny krzyk, ewentualna fizyczna konfrontacja z niezadowolonym graczem) ${ }^{99}$. Kobiety organizatorkami gier bywały przypadkowo, $\mathrm{z}$ reguły w zastępstwie męża ${ }^{100}$. Niewykluczone, że znaczenie miały również uwarunkowania kulturowe, w tym np. społeczna akceptacja hazardu jako rozrywki dla mężczyzn i przez nich organizowanej ${ }^{101}$. Odbiciem tego typu myślenia pozostaja uwagi ówczesnych dziennikarzy piszących o hazardzie ${ }^{102}$.

Wśród 116 mężczyzn wyraźnie dominowali chrześcijanie (95 osób, 82 proc.). W grupie kilkunastu recydywistów znalazła się tylko jedna osoba wyznania mojżeszowego. Był to Rubin Kernsztejn, który dwukrotnie w 1937 r. stanął przed obliczem Sądu Okręgowego w Wilnie za organizację w Krewie gry w kości ${ }^{103}$. Wyznanie organizatora gry decydowało często o jej formie. W grupie mężczyzn chrześcijan (78 osób) blisko 70 proc. $\mathrm{z}$ nich organizowało proste loterie fantowe. Tymczasem w niewielkiej liczebnie (22 osoby) grupie mężczyzn Żydów, najczęściej

wysoki. W związku z tym, że nie było jej stać na grzywnę, do aresztu w Święcinach trafiła na 17 dni. Trudno wyrokować, co mogło być bezpośrednią przyczyną takiej decyzji sędziego, kwestii płci nie możemy wykluczyć. Być może znaczenie miało tu również wyznanie oskarżonej. Wiadomo na pewno, że doniósł na nią jeden z klientów, chrześcijanin. Por. Akta sprawy Luby Mauber, 1934, LCVA, PSO, sygn. 54157.

${ }^{97}$ W XIX w. odnotowuje się przypadki kobiet prowadzących kolektury loteryjne, przy czym jeśli wyszły one za mąż, kolekturami zarządzali już mężczyźni. Por. A. Nowak, op. cit., s. 139. Inaczej w nowojorskim Harlemie, gdzie historycy odnotowują obecność kilku bardzo wpływowych kobiet, które odegrały ważną rolę w rozwoju gier liczbowych. Por. S. White, S. Garton, S. Robertson, G. White, op. cit., s. 159-163.

${ }_{98}$ Pamiętniki bezrobotnych, nr 1-5, oprac. L. Krzywicki, Warszawa 1933, nr 3, s. 45.

99 Ibidem.

100 „Z chwilą znalezienia się małżonków pod kluczem, próbują zluzować ich «na posterunku» dzielne ich połowice, ale i tym się niezbyt udaje proceder!”, „Popadła się” Franciszka!, KN 2 II 1935, 32, s. 7.

101 W stołecznych „ruleciarniach” również rzadko spotyka się kobiety. Są one z reguły towarzyszkami mężczyzn, pełnią rolę osób obsługujących grających. Por. M. Rodak, op. cit.
102 S. Morton, op. cit., s. $69 \mathrm{nn}$.
103 Akta sprawy Rubina Kernsztejna, 1937-1938, LCVA, PSO, sygn. 54240, 54260. 
zatrzymywanych w miastach, loterie fantowe urządzała tylko $1 / \frac{1}{4} \mathrm{z}$ nich. Proporcjonalnie częściej Żydów karano za udostępnianie aparatów Suchard, to oczywiście skutek struktury zawodowej, oraz za organizację popularniejszej w mieście gry w kości.

Wśród 125 osób, których wiek odnotowano, wyraźnie dominują oskarżeni w wieku od 31 do 40 lat. Stanowili w sumie ponad 45 proc. całej próby (57 osób) ${ }^{104}$. Drugą pod względem liczebności grupę tworzyli ludzie młodsi, tj. w wieku do 30 lat (42 osoby, 34 proc.). Organizatorzy gier loteryjnych, którzy skończyli 40 lat i więcej stanowili około 1/5 całej próby (26 osób, 21 proc.). Osoby poniżej 20 roku życia, podobnie jak oskarżeni, którzy skończyli 55 lat, tworzyli najmniejszą część grupy ${ }^{105}$. Wydaje się więc, że przygodę z drobnym hazardem najczęściej rozpoczynano wraz z opuszczeniem domu rodzinnego. Wkraczający na rynek pracy dwudziestolatkowie, którzy szczególnie w czasach kryzysu nie mogli znaleźć zatrudnienia, imali się różnych zajęć, w tym tych, w których balansowano na granicy prawa. $Z$ biegiem lat, nawet jeśli organizowali gry okazjonalnie, nabierali doświadczenia. Dominacja trzydziestolatków to także w jakimś stopniu efekt kryzysu i wzrostu bezrobocia. Po kilku latach spędzonych w gospodarstwie rodziców, względnie pracy dorywczej na wsi czy mieście, którą w latach trzydziestych tracili, rozpoczynał się etap włóczęgi. Jednym z dostępnych sposobów zarobkowania stawał się handel obwoźny, a szansą na podniesienie dochodów organizacja loterii, najczęściej bez zgody władz skarbowych. Jednocześnie zaawansowany wiek nie ułatwiał znoszenia trudów wędrówki.

Najczęściej tłumaczono się biedą ${ }^{106}$. Bezrobotny pamiętnikarz pisał, pełen obaw, wprost: „Przecież tej pracy nie podjąłby się żaden

104 Generalnie średnia wynosiła nieco ponad 34 lata, a mediana 33 lata.

105 Struktura wiekowa przekładała się na dane dotyczące stanu cywilnego. Generalnie dominowali oskarżeni, którzy byli w związkach małżeńskich. Stosunkowo niewielką grupę stanowili kawalerowie/panny. Niestety informacje na temat stanu cywilnego pojawiały się rzadko. Niemniej wydaje się, że konieczność utrzymania rodziny mogła wpływać na decyzję o wyborze niezgodnej z prawem formy zarobkowania. Skazany na 60 zł grzywny i dwa dni aresztu rolnik ze wsi Iszoryszki w powiecie wileńsko-trockim, gospodarujący na 4 ha, właściciel domu, chlewa, dwóch świń, konia, krowy, a przede wszystkim mający na utrzymaniu szóstkę dzieci, przyznał się, że grę w kości zorganizował, żeby dorobić, ponieważ w domu panowała nędza, Akta sprawy Wincentego Maciekjańca, 1935, LCVA, PSO, sygn. 54200.

106 Tytułem przykładu: Akta sprawy Michała Szydłowskiego, 1937, LCVA, PSO, sygn. 54250; Akta sprawy Anny Litwinko, 1934, ibidem, sygn. 54130; Akta sprawy Doby Milchikier, 1934, ibidem, sygn. 54120; Akta sprawy Józefa Sperskiego, 1933-1934, ibidem, sygn. 54158; Akta sprawy Witolda Judyckiego, 1933-1934, ibidem, sygn. 54158. Judycki, recydywista z Wilna, mieszkał w jednoizbowym mieszkaniu z trójką dzieci i żoną, żył z opieki społecznej, zeznał, że od czterech miesięcy zalegał z komornym wynoszącym 15 zł. 
z szanujących ludzi, uważałby to za upokorzenie, a ja biedą zmuszony robię z siebie pośmiewisko" i dodawał: "Jestem głodny i dlatego muszę [sprzedawać cukierki]"107. O tym, że było to środowisko skupiające osoby dotknięte plagą bezrobocia, świadczą szczątkowe dane o ich zatrudnieniu. Wśród blisko 80 osób, które przedstawiły w sądzie swoją aktualną sytuację zawodową, blisko połowa przyznała, że jest bez pracy. Do tej grupy należałoby doliczyć oskarżonych, którzy zadeklarowali, że żyli z obwoźnego handlu cukierkami ${ }^{108}$. Odnotowuje się również widoczną obecność dorabiających w ten sposób rolników, a w miastach robotników ${ }^{109}$.

Potwierdzeniem niskiego statusu materialnego członków badanego środowiska pozostaje fakt, że $3 / 4 \mathrm{z}$ nich nie było stać na zapłacenie grzywny. Wiązało się to z koniecznością odbycia dodatkowych kar aresztu. Przy czym kwoty grzywien bywały bardzo wysokie $(\bar{x}=193$ zł, mieściły się $\mathrm{w}$ przedziale od 5 do $600 \mathrm{zł}$ ). Najczęściej wymierzaną karą była grzywna w wysokości 500 zł z zamianą na karę aresztu od 5 do 25 dni (30,2 proc. czyli 35 przypadków). W sumie w dostępnej próbie grzywny równe lub wyższe niż 100 zł nałożono na 60 osób (52 proc.)! Dużą grupę stanowiły sprawy, w których ukarano oskarżonych grzywną w wysokości 20 zł (18 proc.). Najrzadziej wileński Sąd Okręgowy nakładał najniższą karę, tj. grzywnę w wysokości 5 zł (tylko dwa przypadki). Naturalnie surowiej karani byli recydywiści. W tej grupie wyroki powyżej 500 zł stanowiły ponad połowę przypadków. W kilkunastu sprawach mamy do czynienia z loteryjnymi recydywistami, którzy doczekali się wyroków łącznych za kilka popełnionych wykroczeń. Stanisław Kalinowski z Wilna pod koniec 1934 r. skazany został wyrokiem łącznym na zapłacenie grzywny w wysokości 2020 zł z zamianą na 58 dni aresztu oraz karą aresztu na 1,5 miesiąca ${ }^{110}$. Wyższe kary wymierzano przede wszystkim osobom, które działały na terenie Wilna lub z niego pochodziły ${ }^{111}$.

107 Pamiętniki bezrobotnych, nr 3, s. 45. Jedno z niewielu zachowanych świadectw, w których bezrobotny warszawski opisuje swoje wrażenia jako handlarz „pudełek szczęścia”. Pamiętnikarz pisał m.in. o swoich obawach i tremie związanej z koniecznością reklamowania cukierków: „Od dziecka jestem nieśmiały, a tu stoję na ulicy, wszyscy na mnie patrzą, a ja się drę jak wariat i sprzedaję pudełka szczęścia”.

108 Ibidem.

${ }^{109}$ Mało prawdopodobne wydają się sytuacje, które notujemy wśród organizatorów gier liczbowych w Nowym Jorku, kiedy część z nich stawała się zamożnymi ludźmi, S. White, S. Garton, S. Robertson, G. White, op. cit., s. 147 nn.

110 Akta sprawy Stanisława Kalinowskiego, 1934-1935, LCVA, PSO, sygn. 54102, 54161 i 54167.

111 Por. Akta sprawy Ignacego Kościuka, 1934-1935, LCVA, PSO, sygn. 54182 (w sumie cztery sprawy za organizację loterii i gry w kości, skazany wyrokiem łącznym na zapłacenie grzywny w wysokości 1600 zł z zamianą na 14 dni oraz na miesiąc aresztu). 
Czym tłumaczyć tę surowość wileńskiego sądu? W gruncie rzeczy analizuję w tym miejscu rodzaj przestępstwa, którego szkodliwość ekonomiczna nie była szczególnie wysoka. Dochód takiego „przedsiębiorstwa” był z reguły bardzo niski. Jednocześnie nie było to zjawisko masowe, na pewno nie na tyle powszechne, aby poważnie zachwiać dochodami państwa ${ }^{112}$. Analiza kilku zachowanych uzasadnień do wyroków pozwala przypuszczać, że kluczową rolę odgrywać mogła jego potencjalna szkodliwość społeczna. Wydaje się, że wileńscy sędziowie, podobnie zapewne jak ich koledzy w innych województwach, traktowali zagrożenie uzależnieniem od hazardu jako poważne i realne. Trudno wskazać, czy był to efekt codziennych obserwacji społecznych, czy może odbicie obowiązujących schematów myślowych na temat hazardu jako takiego.

Kończąc tę krótką próbę opisu środowiska organizatorów gier, warto jeszcze zastanowić się nad tym, skąd pochodzili i zestawić te dane z informacjami o obszarze, na którym działali. Ponad połowa oskarżonych o organizację nielegalnych loterii pochodziła ze wsi. Kolejną grupę pod względem liczebności stanowili mieszkańcy Wilna (28 proc.) oraz innych miast (18 proc.), w tym Warszawy (dwie osoby) czy Brześcia nad Bugiem (jedna osoba) $)^{113}$. Z pozostałych miast odnotowujemy liczną reprezentację osób urodzonych w Lidzie i Mołodecznie. Poza Wilnem, miastem na prawach powiatu, najczęściej oskarżeni pochodzili z powiatów: wileńsko-trockiego (10), dziśnieńskiego (10), święciańskiego (10), wołożyńskiego (9), mołodeczańskiego (8) oraz brasławskiego (7).

Znacznie bardziej interesujące są informacje na temat obszaru, na którym działali loteryjni „przestępcy”. W tym przypadku spada znaczenie miast, w tym również i Wilna. Zaledwie co piąta zakwestionowana loteria odbyła się w Wilnie. W stolicy województwa, tak jak w innych dużych miastach, dostępne były konkurencyjne oferty: gry w trzy karty, trzy blaszki, miejsca, gdzie można było grać w karty, nielegalne kasyna itd. Potwierdza się natomiast dominacja wsi, na terenie których odbyło się blisko $2 / 3$ (59 proc.) zakwestionowanych przez urzędników gier. Pozostałe sprawy dotyczyły innych miast(eczek), m.in. Wołożna, Iwieńca, Lidy czy Szczuczyna ${ }^{114}$.

W 1937 r. na pół roku więzienia skazany został wyrokiem łącznym (w sumie pięć spraw) recydywista Witold Judycki z Wilna, Akta sprawy Witolda Judyckiego, 1933-1934, ibidem, sygn. 54158, 54191.

${ }^{112}$ W gruncie rzeczy nie pozwalała na to specyfika loterii, wśród których nie występowały loterie pieniężne. Tam, gdzie notowano ich obecność i to na znaczną skalę, stanowiły ważny element finansowy „szarej strefy”. Por. S. Louw, op. cit., s. 35.

${ }_{113}$ Miejsce urodzenia dwóch osób nie jest znane.

114 Por. przyp. 9. Sąd Okręgowy w Wilnie obejmował również północne powiaty województwa nowogrodzkiego. 
Mapa 1. Natężenie występowania zjawiska organizacji nielegalnych loterii w latach 1927-1939 wg powiatów

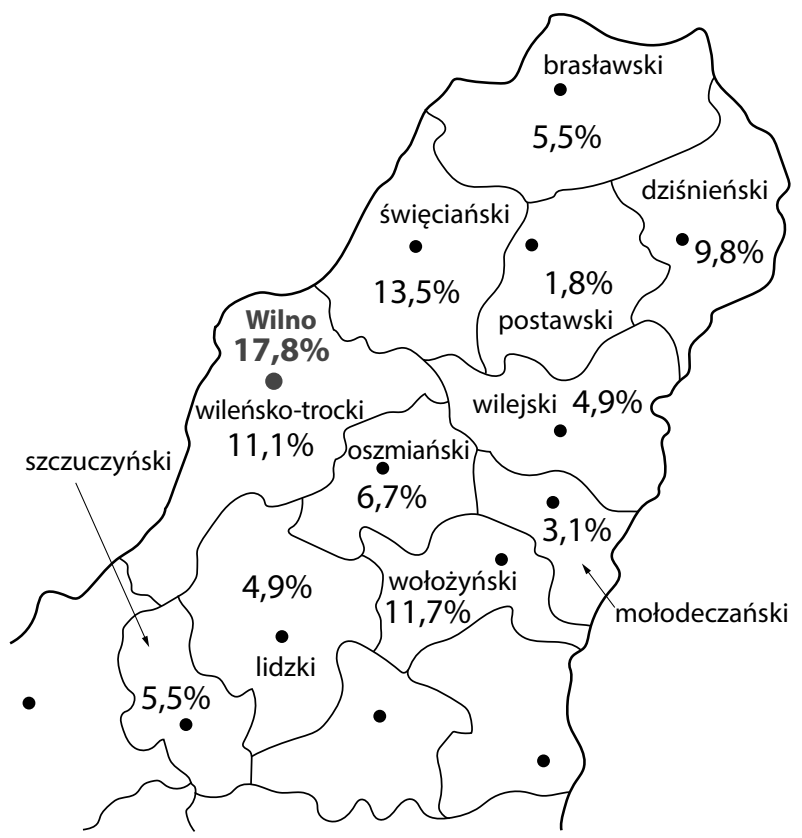

Źródło: Lietuvos Centrinis Valstybės Archyvas, Prokuratura Sądu Okręgowego w Wilnie.

Były to jednak, tak jak w przypadku Mołodeczna, Brasławia, Głębokiego czy Trok, pojedyncze przypadki. Poza Wilnem loterie urządzano najczęściej w powiatach: święciańskim, wołożyńskim (woj. nowogrodzkie), wileńsko-trockim, dziśnieńskim i oszmiańskim. W pozostałych powiatach, w tym m.in. lidzkim czy szczucińskim, liczba oprotestowanych gier nie przekraczała dziesięciu. Najrzadziej kontrolerzy skarbowi trafiali na nielegalne loterie w powiecie postawskim (tylko trzy przypadki) ${ }^{115}$.

Generalnie, jak wynika z mapy, znacznie częściej wykrywano nielegalne loterie w samym Wilnie i powiatach sąsiadujących ze stolicą województwa. Niewykluczone, że był to efekt większej aktywności kontrolerów, którzy z większą częstotliwością i w większej liczbie przeprowadzali tam stosowne kontrole skarbowe. Analogicznie patrolujący ulice, rynki i targi policjanci mogli częściej zgłaszać zaobserwowane wykroczenia. Przypomnijmy, że urzędy skarbowe akcyz i monopoli skarbowych mieściły się w Wilnie i Wilejce, a także w Lidzie. Bliskość instytucji nadzorujących z pewnością wpływała na intensywność kontroli. Kluczem

115 W sześciu przypadkach nie znamy powiatu, w którym urządzono loterię. 
do rozwiązania zagadki mogą być także stosunki ludnościowe w powiatach $^{116}$. Obserwujemy bowiem wyraźną korelację pomiędzy liczbą wykrytych nielegalnych loterii a liczbą ludności zamieszkującej dany teren. Więcej loterii odbywało się w tych powiatach, które były ludniejsze (np. w dziśnieńskim mieszkało około 159 tys. mieszkańców, a w postawskim już tylko 99,9 tys., najmniejszą liczbę mieszkańców miał powiat mołodeczański - 91 tys.) ${ }^{117}$. Mówiąc wprost, organizatorzy loterii, szukając rynków zbytu na swoje usługi, robili to tam, gdzie ze względu na gęstość zaludnienia mieli większe szanse znaleźć osoby chętne do gry.

Wydaje się również, że mógł istnieć związek między częstotliwością organizowanych gier a stosunkami wyznaniowymi w powiatach. Znacznie więcej odbywało się tam, gdzie dominowała ludność rzymskokatolicka (w większości Polacy) oraz Żydzi. Im więcej ludności prawosławnej (głównie Białorusini), tym mniej tego typu rozrywek. Niemniej dostępna próba jest stosunkowo nieduża, stąd wnioski płynące z zastosowania w tym miejscu korelacji potraktować należy jako ewentualny punkt wyjścia w rozważaniach o szerszym charakterze ${ }^{118}$.

Najbardziej mobilni pozostawali mieszkańcy Wilna, którzy ze swoimi przenośnymi loteriami najczęściej odwiedzali sąsiednie powiaty. Blisko połowa spośród 52 wilnian, którzy stanęli przed obliczem Sądu Okręgowego, organizowała loterie poza stolicą województwa. Przede wszystkim udawali się na teren powiatu wileńsko-trockiego, a także powiatów: święciańskiego, oszmiańskiego i lidzkiego. Co zaskakujące, żaden z nich nie odwiedził powiatu wilejskiego. Niewykluczone, że wpływ na to miała bardzo rzadka siatka dróg, którymi można było dotrzeć do tego powiatu. Do Wilejki najlepsza droga, w tym kolejowa, prowadziła przez Mołodeczno. Jednocześnie organizatorzy gier spoza Wilna tylko z drobnymi wyjątkami decydowali się szukać okazji do zarobku w stolicy województwa. Hazardowy rynek wileński zmonopolizowany był w całości przez miejscowych „krupierów”. Jeszcze tylko organizatorzy gier

116 Wydaje się, że nie ma większego znaczenia wielkość powiatów.

117 Drugi powszechny spis ludności z dn. 9 XII 1931 r. Mieszkania i gospodarstwa domowe. Ludność. Stosunki zawodowe. Województwo wileńskie, bez miasta Wilna, Warszawa 1936, s. 1.

118 W literaturze przedmiotu porusza się problematykę związków między wyznaniem/religią, a hazardem i jego licznymi formami, S. Morton, op. cit., s. $108 \mathrm{nn}$. Autorka porusza różnice między podejściem Kościołów katolickiego i protestanckiego. K.K. Weaver, „It's the Union Man That Holds the Winning Hand”. Gambling in Pennsylvania's Anthracite Region, „Pennsylvania History. A Journal of Mid-Atlantic Studies” 80, 2013, 3, s. 408. Autorka podnosi kwestie przychylnego stosunku Kościoła katolickiego do hazardu w środowisku górników w Pensylwanii. W mniejszym stopniu praktyka organizowania loterii spotykana była również w Polsce międzywojennej. Przy czym angażowano do ich organizacji, jak się wydaje, przede wszystkim mężczyzn. 
z powiatu mołodeczańskiego „masowo” opuszczali swój rodzinny powiat (z 12 osób pochodzących z tego powiatu, aż 9 działało na terenie pozostałych powiatów). Bywali nawet w powiecie dziśnieńskim, do którego przybywało wielu operujących na terenie województwa organizatorów loterii. Niemniej rejonami, w których notujemy największy napływ osób spoza nich, pozostawały powiaty: święciański (wśród 22 działających tam osób aż 10 pochodziło spoza powiatu), wileńsko-trocki, wołożyński oraz oszmiański. Wydaje się więc, że na „popularność” konkretnych obszarów wpływ miały m.in. względnie gęsta siatka dróg, obecność linii kolejowej (pow. święciański - dwie linie), gęstość zaludnienia, liczba i częstotliwość organizowanych targów, a także bliskość Wilna oraz być może specyfika narodowościowo-wyznaniowa. Obecność dużego ośrodka miejskiego w naturalny sposób generowała więc większą aktywność, tak organizatorów, jak i kontrolerów.

\section{Podsumowanie}

Drobny hazard uliczny był zjawiskiem trwale wpisanym w społeczną panoramę międzywojennych miast i wsi. W loterie, kości, „koła szczęścia" grywano nie tylko na Wileńszczyźnie jeszcze daleko przed $1918 \mathrm{r}$. W Drugiej Rzeczypospolitej większość, jeśli nie wszystkie ośrodki miejskie borykały się z problemem niekontrolowanego rozwoju ilościowego, rzadziej jakościowego, nielegalnych gier quasi-hazardowych. Był to poważny kłopot społeczny, który stał się szczególnie dotkliwy w okresie wielkiego kryzysu. W opinii ówczesnej prasy, nie tylko wileńskiej, jego trwanie niezmiennie traktowano jako zagrożenie dla właściwego funkcjonowania społeczeństwa. Zdanie to, jak należy przypuszczać na podstawie analizy sytuacji w Wilnie, podzielały również, na pewno od pewnego momentu (połowa lat trzydziestych), władze samorządowe oraz policja. Także postawa sędziów, którzy wyjątkowo surowo karali organizatorów drobnych gier hazardowych, wskazuje, że wymiar sprawiedliwości analizowany problem interpretował podobnie jak prasa ${ }^{119}$.

119 Warto odnotować, że wysokie kary grzywny otrzymywali również organizatorzy np. „ruleciarni”. W Warszawie osoby skazane za prowadzenie nielegalnych domów gry karane były grzywnami od 1500 do 3000 zł. Por. Warszawskie Monte Carlo zlikwidowane przez policję w Al. Jerozolimskich, „Dzień Dobry” 6 X 1933, 277, s. 8; Surowe kary na właścicieli potajemnych ruletek, „Polska Zbrojna” 6 X 1933, 277, s. 7; Kary na organizatorów ruletki, „Polska Zbrojna" 15 IV 1934, 101, s. 5. Przy czym mowa tu o wielokrotnych recydywistach, osobach nierzadko zamożnych, które stać było na płacenie kaucji w kwotach od 300 do $500 \mathrm{zł}$. Niejednokrotnie łączących szulerstwo, organizację gier, życie z oszustw i kradzieży. 
Szczególnie wiele miejsca dzienniki wileńskie poświęcały kwestii masowego uczestnictwa w grach dzieci i młodzieży. Z obawą pisano o ludności ubogiej, dla której tego typu rozrywka stanowiła jedną z niewielu dostępnych form spędzania wolnego czasu. Przy czym proponowano w zasadzie jedno rozwiązanie, tj. całkowity zakaz prowadzenia loterii oraz systematyczne i seryjne aresztowania organizatorów gier. Niewiele możemy powiedzieć o samych graczach, wśród których rzeczywiście, jak można przypuszczać na podstawie lektury prasy i pojedynczych wzmianek w aktach sądowych, dominowali mężczyźni w różnym wieku. W zdecydowanej większości przypadków byli to przedstawiciele uboższych warstw, dzieci, młodzież, żołnierze. Naturalnie na wsi najliczniejszą grupę graczy i przypadkowych obserwatorów stanowili włościanie, przede wszystkim młodzi i w średnim wieku.

Wśród graczy, podobnie jak w przypadku organizatorów, rzadko spotykamy kobiety ${ }^{120}$. Mogło to wynikać z kilku powodów. Mężczyźni na targu, jarmarku czy odpuście bywali w innych celach niż kobiety (np. wizyta w karczmie). Być może mieli więc nieco więcej wolnego czasu. Tym bardziej, kiedy jako bezrobotni bez celu krążyli po ulicach. Być może jakąś rolę odgrywał wypity wcześniej alkohol. Część badaczy odwołuje się do teorii, według których udział w grach hazardowych mężczyzn to efekt ich skłonności do podejmowania ryzyka ${ }^{121}$. Jednocześnie w prasie kobiety przedstawiane były jako osoby naiwne, grające pod wpływem impulsu ${ }^{122}$.

${ }^{120}$ W północnoamerykańskich środowiskach robotniczych, i nie tylko tam, odnotowuje się dla okresu międzywojennego wysoki odsetek kobiet grających w bingo. Historycy zwracają jednocześnie uwagę na ich negatywny odbiór społeczny, S. Morton, op. cit., s. 90-91, 95-96. Por. również rozważania na temat kobiet jako graczek, E. Casey, Women, pleasure and the gambling experience, Aldershot-Burlington 2008, passim.

${ }^{121}$ K.K. Weaver, op. cit., s. 415-416. Przy okazji zwycięzcy zyskują w oczach innych graczy jako osoby zaradne i odważne. Co interesujące, badaczka hazardu wśród górników pensylwańskich pisze, że udział w loteriach pozostawał domeną kobiet. Tymczasem mężczyźni z reguły grali w karty, kości oraz emocjonowali się walkami kogutów lub wyścigami gołębi. Tego typu form rozrywki w Polsce nie spotkałem. Por. rozważania na temat społecznego odbioru mężczyzn jako graczy, w tym ich skłonności do ryzyka (również picia alkoholu, wizyt u prostytutek, stosowania przemocy itd.), które łączono z męskością jako taką, S. Morton, op. cit., s. $70 \mathrm{nn}$.

122 Włod., Hazard Wilna. Imprezy bardzo szkodliwe, KW 31 VIII 1934, 237, s. 6; „Oto podchodzi do stolika młoda niewiasta. Obserwuje grę. W pewnej chwili podniecona kładzie rękę na krążku i mówi, wyjmując monetę pięciozłotową - Stawiam dwa złote!”, Hazard Jadwigi, KN 19 XI 1934, 317, s. 4; „,Może panienka zagra? Nie wielka sztuka, a można wygrać duże pieniądze! - kusił ją pierwszy, miętosząc w ręku brudne karty. - Kiedy ja nie wiem jak? - odpowiedziała niezdecydowanie pani Jadzia, jednak nie odchodziła, bowiem demon gry począł ją brać w swą władzę", ibidem. 
Co interesujące, gracze nie mają wyznania ani narodowości. W dostępnych źródłach kwestia ta w ogóle się nie pojawiała ${ }^{123}$.

Zachowana dokumentacja sądowa pozwala sformułować tezę, że między graczami i organizatorami obowiązywał nieformalny konsensus. Niezwykle rzadko bowiem przegrani domagali się rekompensaty, względnie wyrażali żal z powodu przegranych, a w konsekwencji donosili policji czy kontrolerom skarbowym o toczącej się grze ${ }^{124}$. Wzajemnie tolerowano ułomności drugiej strony. Gracze godzili się na udział w przedstawieniu miernej jakości, organizatorzy nie oczekiwali od graczy gotowości do stawiania wygórowanych stawek, ciesząc się każdym zarobkiem. Z racji ograniczonej liczby dostępnych form rozrywki i jedni, i drudzy byli sobie wzajemnie potrzebni. Jednocześnie profil społeczny środowiska organizatorów loterii, gier w kości czy „kół szczęścia” wyraźnie wskazuje, że była to grupa osób wywodzących się z tych samych warstw, z których pochodzili gracze. Przy czym warto w tym miejscu sformułować postulat głębszych badań zjawiska, w których uwzględni się jego rolę w środowiskach stricte robotniczych (Katowice, Sosnowiec, Łódź).

Loteria państwowa, pomimo swojej powszechności, była rozrywką okazjonalną i nie najtańszą. W okresie kryzysu pojedynczy los kosztował $32 \mathrm{z}^{125}$. Stąd często wybierano zakup $1 / 4$ losu (ewentualna wygrana wynosiła wówczas $1 / 4$ puli) lub zakup jednego losu przez kilka osób ${ }^{126}$. Dla wielu mieszkańców Polski międzywojennej wspomniana kwota stanowiła barierę nie do przejścia. Dotyczyło to przede wszystkim mieszkańców wsi, przedstawicieli strukturalnej miejskiej biedoty, ludzi młodych lub dzieci, które nie mogły nabywać losów. W okresie kryzysu do tej grupy dołączyło liczne grono bezrobotnych, których wraz z utrzymującą się sytuacją ekonomiczną coraz rzadziej było stać na kupno nawet ćwiartki losu. Nie bez znaczenia wydaje się również druga ze wskazanych tu cech ówczesnej loterii państwowej. Dwa, z czasem trzy losowania w ciągu roku nie zaspakajały społecznego zapotrzebowania na tego typu rozrywkę.

${ }^{123}$ Inaczej w XIX w., kiedy jako gracze wyjątkowo często pojawiała się głównie uboga ludność żydowska, por. A. Nowak, op. cit., s. 200-201. W międzywojennej Kanadzie z hazardem jako takim powszechnie kojarzone były środowiska kanadyjskich Chińczyków oraz Żydów, por. S. Morton, op. cit., s. 108-110.

${ }^{124}$ W zachowanym materiale odnalazłem tylko jeden taki przypadek. Por. Akta sprawy Franciszka Kondratowicza, 1934-1935, LCVA, PSO, sygn. 54075. Przy czym indagowani przez urzędników włościanie nie tyle skarżyli się na wynik gry, co szczegółowo opisali zakwestionowany proceder.

125 P. Grata, Monopol loteryjny, s. 135.

126 Ibidem. 
Już tylko te dwa fakty realnie ograniczały szansę na to, by wpaść w sidła loteryjnego hazardu. „Kurier Wileński” w 1939 r. mógł z czystym sumieniem reklamować 44 loterię klasową, dowodząc, że „znajduje się [loteria] niejako na marginesie życia. Stanowi nie potrawę, ale przyprawę, dodawaną w nieznacznej stosunkowo ilości"127. Udział w loterii był, zdaniem dziennika, zaledwie niewinnym flirtem z losem. Czym innym miał być hazard - „spółką zawartą z losem na zasadach odpowiedzialności nieograniczonej i nierozgraniczonej" ${ }^{22}$.

Przy tak ograniczonej legalnej ofercie państwowej społeczno-ekonomiczną odpowiedzią na zapotrzebowanie części międzywojennego społeczeństwa, szczególnie tej ubogiej lub najuboższej, pozostawały setki nielegalnych lub półlegalnych, drobnych, jednoosobowych inicjatyw prywatnych. Na ulicach ówczesnych miast, a także w miejscach, w których gromadzili się mieszkańcy wsi i miast, a więc na wszelkiego rodzaju jarmarkach, targach, odpustach, placach, rynkach, w parkach czy wesołych miasteczkach, można było spotkać „przedsiębiorców” oferujących cały katalog rozrywek, w tym loterii, gier hazardowych czy zręcznościowych. W końcu także oszustów, którzy oferowali rozrywki w typie gry w trzy blaszki czy karty. Nie były to zjawiska nowe. Alicja Nowak w pracy poświęconej loterii w Królestwie Polskim pisze, że zjawisko jarmarcznych, drobnych loterii notowane było już w XVII w. ${ }^{129}$ Co symptomatyczne, charakter tego typu form rozrywki w zasadzie nie zmienił się do XX w. Nie uległ również radykalnym zmianom dyskurs, który ich dotyczył. Bezwzględnie traktowano je jako zgrzebną, niemniej bardzo niebezpieczną, wersję hazardu lub jako formę oszustwa. Nie zmienia to jednak faktu, że w zasadzie długo jeszcze jedyną dostępną, a przy tym budzącą niebezpieczne emocje oraz cieszącą się sporą popularnością.

\section{Streszczenie}

Drobny „przemysł” loteryjny wpisany był w pejzaż polskiej prowincji co najmniej od XVII w. Już w kolejnym stuleciu pojawiły się pierwsze próby uporządkowania systemu loteryjnego, z czasem wprowadzono monopol państwowy. W Drugiej Rzeczypospolitej już od 1919 r. państwo zagwarantowało sobie prawo do prowadzenia loterii oraz wydawania instytucjom i osobom prywatnym pozwoleń na jej organizację. Losy loterii państwowej, tym bardziej kupon na wyścigach konnych, nie

${ }^{127}$ Margines fantazji, KW 16 II 1939, 47, s. 6.

128 Ibidem.

129 A. Nowak, op. cit., s. 42-43. 
należały jednak do tanich. Jednocześnie były to rozrywki dostępne stosunkowo rzadko, zarezerwowane raczej dla mieszkańców większych lub średnich miast. Tymczasem zapotrzebowanie na rozrywkę połączoną z ryzykiem i ewentualną szansą na wygranie dotyczyło znacznie większej części społeczeństwa. Odpowiedzią na nie pozostawał, opisywany wówczas jako „drobny” czy „pokątny”, hazard uliczny. Na wiejskich targach, jarmarkach czy odpustach, w miejskich parkach, skwerach czy wprost na ulicach zjawiskiem powszechnym była grupa osób, przede wszystkim mężczyzn, skupionych wokół stolików, przy których grano w niewyszukane gry quasi-hazardowe.

Artykuł stanowi wstępną próbę opisu tego zjawiska w Drugiej Rzeczypospolitej na przykładzie województwa wileńskiego. Bazę źródłową stanowią akta prokuratury przy Sądzie Okręgowym w Wilnie z lat 1922-1939 oraz lokalna prasa. W artykule skupiam się na prezentacji trzech węzłowych problemów. Pierwszym z nich pozostaje próba odpowiedzi na pytanie o to, czy opisywana forma rozrywki może zostać potraktowana jako przejaw szerszego fenomenu, jakim pozostawał międzywojenny „przemysł” hazardowy (stąd określenie quasi-hazard). Prezentuję ogólne założenia ówczesnego systemu monopolu loteryjnego, a na tym tle przedstawiam charakterystykę najczęściej spotykanych form gier oraz pojawiających się przy ich klasyfikacji wątpliwości interpretacyjnych. Część druga to analiza dyskursu prasowego. W części ostatniej przyglądam się środowisku organizatorów tego typu gier oraz w mniejszym już stopniu samym graczom.

\section{The Phenomenon of Street Gambling in the Second Polish Republic. The Case of the Vilnius Voivodeship}

The small lottery 'industry' was inscribed in the landscape of the Polish province at least from the seventeenth century. As soon as the next century, the first attempts to organize the lottery system were made, and in time, a state monopoly was introduced. In 1919, in the early years of the Second Polish Republic, the state guaranteed itself the right to run a lottery and issue permits to institutions and individuals to organize it. However, state lottery tickets, especially horse racing coupons, were not cheap, apart from the fact that these were entertainment available relatively rarely, reserved for residents of larger or medium-sized towns and cities. At the same time, the need for entertainment with the consciousness of risk and hope of gain was felt by a much larger part of society. The answer to them was street gambling, at that time described as 'petty' or 'backstreet'. It was fairly common to see, at village fairs, markets or church fairs, in town parks, squares or right in the streets, a group of people, mainly men, gathered around tables at which simple (quasi)gambling games were played.

The article is a preliminary attempt to describe this phenomenon in the Second Polish Republic on the example of the Vilnius Voivodeship. The source base is the prosecutor's office files at the District Court in Vilnius from 1922-1939 and the local press. In this article, I focus on the presentation of three fundamental problems. The first attempts to answer whether the described form of entertainment 
can be treated as a manifestation of a broader phenomenon, the interwar gambling 'industry' (hence the term 'quasi-gambling'). I present the general assumptions of the lottery monopoly system from that period, and against this background, I give the characteristics of the most common forms of games and the interpretation doubts arising in their classification. The second part is an analysis of the discourse in the press. In the last part, I look at the milieu of the organizers and, to a lesser extent, the players themselves.

\title{
Bibliografia
}

\author{
Edycje źródłowe
}

Drugi powszechny spis ludności z dn. 9 XII 1931 r. Mieszkania i gospodarstwa domowe. Ludność. Stosunki zawodowe. Województwo wileńskie, bez miasta Wilna, Warszawa 1936. Dziennik Urzędowy Ministerstwa Skarbu, 1927, nr 36, poz. 379.

Dziennik Urzędowy Ministerstwa Skarbu, 1935, nr 36, poz. 843.

Dziennik Ustaw, 1922, poz. 522, Rozporzadzenie Ministra Skarbu z dnia 11 lipca 1922 r. $w$ przedmiocie utworzenia izby skarbowej i urzędów skarbowych na obszarze ziemi Wileńskiej.

Dziennik Ustaw, 1923, poz. 1063, Ustawa z dnia 5 grudnia 1923 r. o rozciagnięciu na obszar...

Dziennik Ustaw, 1924, poz. 541, Rozporzadzenie Ministra Skarbu w porozumieniu $z$ Ministrem Sprawiedliwości z dnia 7 maja 1924 r. dotyczace wykonania ustawy z dnia 26 marca 1920 r. w przedmiocie urzadzenia loterii i założenia...

Dziennik Ustaw, 1926, poz. 609, Ustawa Karna Skarbowa z dnia 2 sierpnia $1926 r$.

Dziennik Ustaw, 1932, poz. 355, Ustawa z dnia 18 marca 1932 r. karna skarbowa.

Dziennik Ustaw, 1936, poz. 581, Dekret Prezydenta Rzeczypospolitej z dnia 3 listopada 1936 r. Prawo karne skarbowe.

Dziennik Ustaw, 1936, poz. 607, Ustawa z dnia 9 lipca 1936 r. o monopolu loteryjnym. „Rozkazy Komendanta Wojewódzkiego Policji Państwowej w Wilnie”, 1930, nr 161

\section{Opracowania}

Casey Emma, Women, pleasure and the gambling experience, Ashgate, Aldershot-Burlington 2008.

Grata Paweł, Monopol loteryjny w Polsce w latach 1920-1939, „Prace Historyczno-Archiwalne" 15, 2005, s. 129-147.

Grata Paweł, Monopole skarbowe w polityce podatkowej Drugiej Rzeczypospolitej, Wydawnictwo Uniwersytetu Rzeszowskiego, Rzeszów 2009.

Kalendarz informator sądowy na 1938 r., oprac. Jerzy Kirkiczenko, Marian Kraczkiewicz, Kazimierz Rudzisz, Warszawa 1938.

Kalendarz informacyjny dla urzędników państwowych na rok 1939, oprac. Józef Meksz, Warszawa 1939. 
Louw Stephen, Numbers Games, Race, Gender, Power. Primitive Accumulation in the Black Metropolis, "Safundi. The Journal of South Africa and America Studiers” 21, 2020, 1, s. 30-53.

Mędrzecki Włodzimierz, Społeczeństwo, w: Wokół nowej syntezy dziejów Drugiej Rzeczypospolitej, red. Włodzimierz Mędrzecki, IH PAN, Warszawa 2019 (Metamorfozy Społeczne, t. 22).

Morton Suzanne, At Odds. Gambling and Canadians 1919-1969, University of Toronto Press, Toronto 2003.

Nowak Alicja, Kupowanie nadziei. Loteria w Królestwie Polskim (1815-1867), Wydawnictwa Uniwersytetu Warszawskiego, Warszawa 2017.

Pamiętniki chłopów, nr 1-51, oprac. Ludwik Krzywicki, Instytut Gospodarstwa Społecznego, Warszawa 1935.

Pamiętniki bezrobotnych, nr 1-5, oprac. Ludwik Krzywicki, Instytut Gospodarstwa Społecznego, Warszawa 1933.

Rodak Mateusz, Nielegalny hazard w II Rzeczypospolitej. Rekonesans badawczy, „Roczniki Dziejów Społecznych i Gospodarczych" 71, 2011, s. 55-82.

Shore Heather, Criminality and Englishness in the Aftermath. The Racecourse Wars of the 1920s, „Twentieth Century British History” 22, 2011, 4, s. 474-497.

Shore Heather, London's Criminal Underworlds, c. 1720 - c. 1930. A Social and Cultural History, Palgrave Macmillan, Basingstoke 2015.

Weaver Karol K., „It's the Union Man That Holds the Winning Hand”. Gambling in Pennsylvania's Anthracite Region, „Pennsylvania History. A Journal of Mid-Atlantic Studies" 80, 2013, 3, s. 401-419.

White Shane, Garton Stephen, Robertson Stephen, White Graham, Playing the Numbers. Gambling in Harlem between the Wars, Harvard University Press, Cambridge Mass. 2010.

Wilk Leszek, Hazard. Studium kryminologiczne i prawne, C. H. Beck, Warszawa 2012.

Biogram: dr hab. Mateusz Rodak, prof. IH PAN; Instytut Historii PAN, Warszawa; zainteresowania naukowe koncentrują się wokół takich zagadnień jak polityka społeczna, szeroko rozumiany „margines społeczny” okresu Drugiej Rzeczypospolitej; kontakt: mateuszrodak@yahoo.pl.

Author: Dr hab. Mateusz Rodak, professor of the Tadeusz Manteuffel Institute of History, Polish Academy of Sciences; his research interests focus on social policy, and the broadly defined 'social margin' of the Second Polish Republic; contact: mateuszrodak@yahoo.pl. 